\title{
Life History of the Spotfin Killifish, Fundulus luciae (Pisces Cyprinodontidae), in Fox Creek Marsh, Virginia
}

\author{
Donald M. Byrne \\ College of William and Mary - Virginia Institute of Marine Science
}

Follow this and additional works at: https://scholarworks.wm.edu/etd

Part of the Fresh Water Studies Commons, Oceanography Commons, and the Zoology Commons

\section{Recommended Citation}

Byrne, Donald M., "Life History of the Spotfin Killifish, Fundulus luciae (Pisces Cyprinodontidae), in Fox Creek Marsh, Virginia" (1976). Dissertations, Theses, and Masters Projects. Paper 1539617475.

https://dx.doi.org/doi:10.25773/v5-rs1b-kg72

This Thesis is brought to you for free and open access by the Theses, Dissertations, \& Master Projects at W\&M ScholarWorks. It has been accepted for inclusion in Dissertations, Theses, and Masters Projects by an authorized administrator of W\&M ScholarWorks. For more information, please contact scholarworks@wm.edu. 


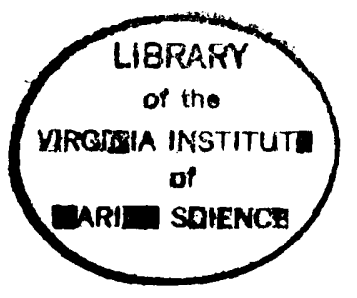

\title{
LIFE HISTORY OF THE SPOTFIN KILLIFISH, FUNDULUS LUCIAE (PISCES: CYPRINODONTIDAE),
}

IN FOX CREEK MARSH, VIRGINIA

\author{
A Thesis \\ Presented to
}

The Faculty of the School of Marine Science

The College of William and Mary in Virginia

In Partial Fulfillment

Of the Requirements for the Degree of

Master of Arts

by

Donald Michael Byrne

1976 
APPROVAL SHEET

This thesis is submitted in partial fulfillment of the requirements for the degree of

Master of Arts
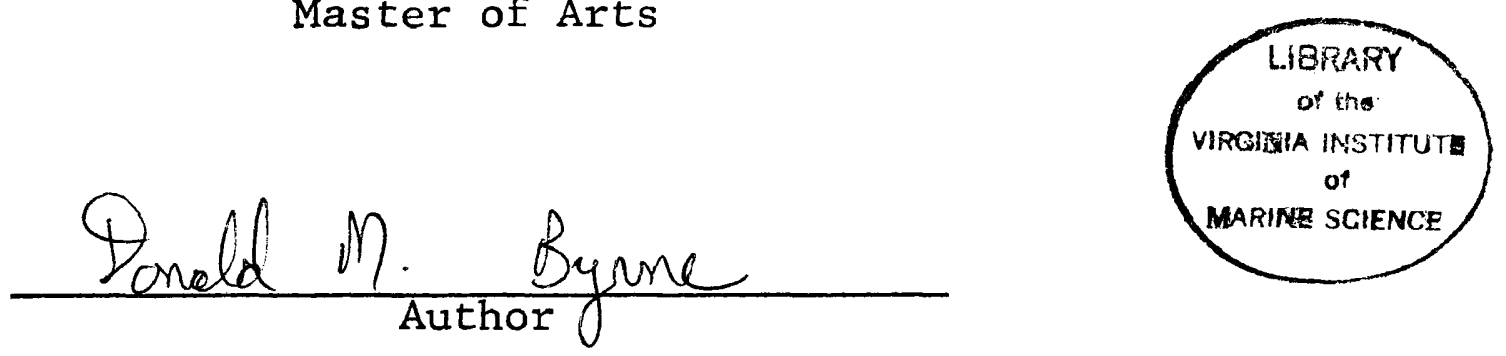

Approved, January 1976
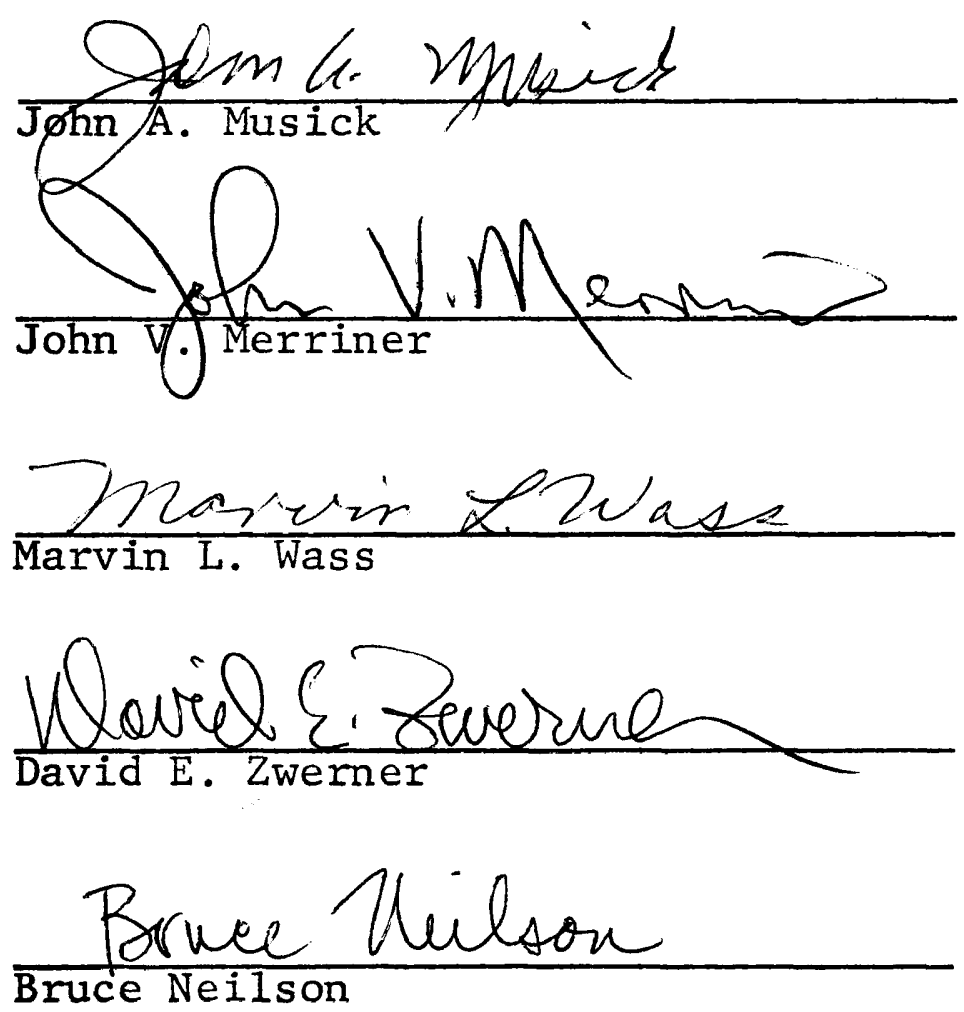

ii 
TABLE OF CONTENTS

Page

ACKNOWLEDGMENTS $\ldots \ldots \ldots \ldots \ldots \ldots \ldots \ldots \ldots \ldots$ iv

LIST OF TABLES..................... v

LIST OF FIGURES......................... vi

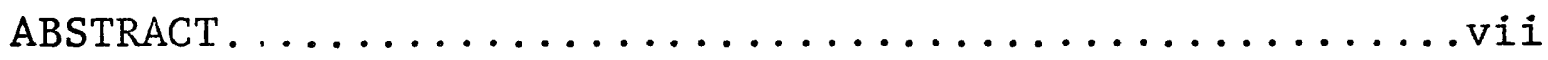

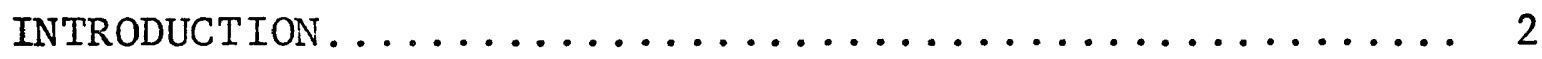

STUDY AREA......................... 4

METHODS AND MATERIALS $\ldots \ldots \ldots \ldots \ldots \ldots \ldots \ldots \ldots \ldots$

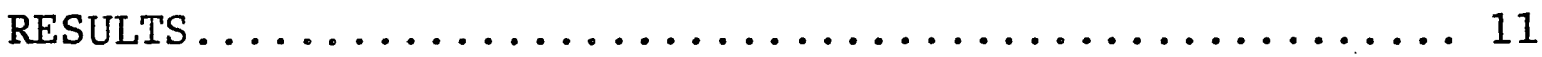

HABITAT.......................... 11

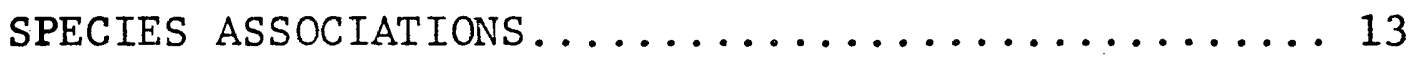

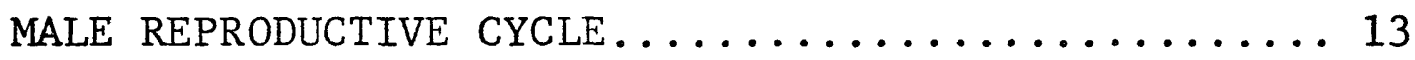

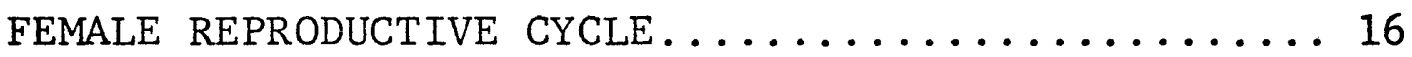

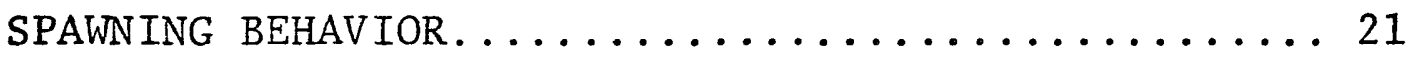

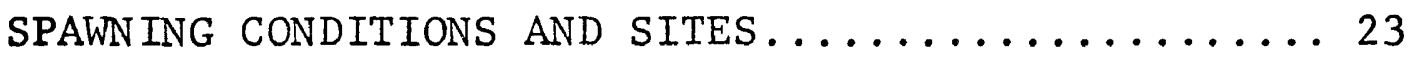

DEVELOPMENT AND GROWTH................ 23

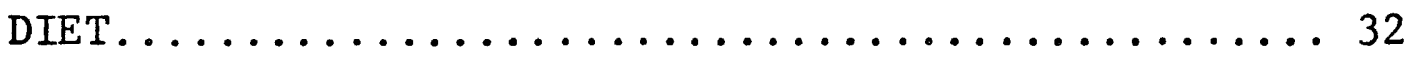

PARASITES ...................... 36

HYBRIDIZATION..................... 41

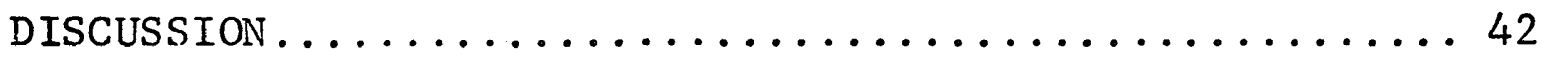

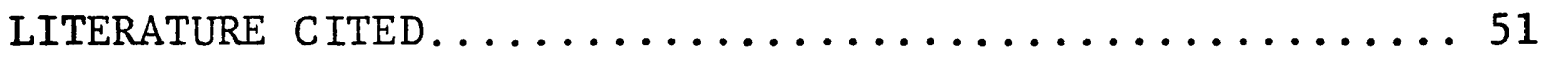




\section{ACKNOWLEDGMENTS}

I wish to express my appreciation to John Musick, my major professor, for his guidance during this investigation, and John Merriner, David Zwerner, Marvin Wass and Bruce Neilson, the members of my thesis committee, for their critical review of the manuscript. Dave Zwerner also generous1y assisted with the identification of parasites.

I am also indebted to Ken $\mathrm{Able}$, who helped initiate the study, Mike Williams, for his careful illustrations, and Debbie Sprinkle, for typing the manuscript. 


\section{LIST OF TABLES}

Table

Page

1. Fecundity of Fundulus luciae by total

length increments and egg size.........17

2. Frequency distribution for eggs $>1.6 \mathrm{~mm}$ diameter in females collected at Fox Creek Marsh from April through August and mean number of eggs per female for each collection date........18

3. Variation in the diameter and number of oil globules per egg of 40 fertilized Fundulus luciae eggs...............19

4. Morphological and meristic measurements of larval and juvenile Fundulus luciae......29

5. Diet of Fundulus luciae..................

6. Metazoan parasites of Fundulus 1uciae.........37

7. Location and frequency of parasites on 341 Fundulus luciae................... 39

8. Growth of Fundulus heteroclitus and Fundulus diaphanus................44 


\section{LIST OF FIGURES}

Figure

Page

1. Map of the York River showing locations where Fundulus luciae was collected.....6 6

2. Distribution of contact organs on an adult male Fundulus luciae............

3. Mature unfertilized ovum, $1.92 \mathrm{~mm}$ in diameter, of Fundulus luciae..........20

4. Fundulus luciae larvae at different stages

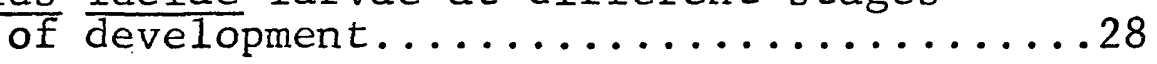

5. Dorsal pigmentation patterns of Fundulus heteroclitus and $\mathrm{F}$. 1uciae larvae.......31 


\section{ABSTRACT}

Fundulus luciae, a rare and poorly known cyprinodont, was collected from a single site throughout a year at Fox Creek Marsh and, occasionally, from other salt marshes along the York River, Virginia. The species occurred in shallow ditches, mudholes and tidal rivulets located in dense stands of Spartina alterniflora in high intertidal areas. These habitats were brackish $(0.2-12.7 \% 0$, sometimes oxygen deficient $(<1 \mathrm{mg} / 1)$ and exhibited seasonal extremes in temperature $\left(4-36^{\circ} \mathrm{C}\right)$.

At Fox Creek Marsh the spawning season extended from mid-April to mid-August. Females contained ova exhibiting continuous gradation of size, but the number of mature and incipient mature ova $(>1.6 \mathrm{~mm}$ diameter) never exceeded 16 per fish. Males possessed contact organs on areas frequently in contact with the female during courtship.

F. luciae larvae were obtained from laboratory fertilized eggs and the Fox Creek Marsh collection site. Meristic and morphologic measurements were made on 27 specimens ranging from 5.3 to $17.0 \mathrm{~mm} \mathrm{TL}(\mathrm{TL}=$ total length).

The juvenile stage was attained at 11-13 mm TL. Sexual maturity occurred at $24-27 \mathrm{~mm}$ TL for males and 28-30 $\mathrm{mm}$ TL for females. The maximum size attained by males was $40 \mathrm{~mm}$ TL and by females, $47 \mathrm{~mm}$ TL. Aging with scales was unsuccessful, but the life span of the species is probably about one year.

Analysis of the contents of 303 digestive tracts showed $\mathrm{F}$. luciae was omnivorous. Detritus, diatoms, ostracods, dipterans and copepods constituted the major components of the diet.

Every major metazoan parasite group, except Cestoda, was represented on $F$. Iuciae. Monogenea were the most numerous, with $57.2 \%$ incidence.

F. luciae is a hardy euryhaline species capable of tolerating rigorous environmental conditions and utilizing a variety of food sources. It is not rare, but apparently restricted to high intertidal marsh areas where it may have been overlooked previously. Its small size, short life span and low fecundity probably prevent a more widespread distribution. 
LIFE HISTORY OF THE SPOTFIN KILLIFISH, FUNDULUS LUCIAE (PISCES: CYPRINODONTIDAE), IN FOX CREEK MARSH, VIRGINIA 
Introduction

Members of the family Cyprinodontidae occur throughout tropical and temperate climates, primarily in fresh, but also in salt and brackish water. In North America the family is represented by several genera, of which the largest is Fundulus. Along the east coast of the United States Fundulus and other killifish species are common inhabitants of shallow water environments, particularly salt and brackish marshes. Ichthyofaunal surveys of such areas frequently show killifishes to be among the most abundant fishes collected (Richards and Castagna 1970). The abundance, widespread distribution, small size, adaptability, and hardiness of these fishes have made them successful laboratory subjects for a variety of research topics in embryology, genetics, physiology, endocrinology, cytology and behavior. Despite such extensive laboratory scrutiny, especially of the mummichog, Fundulus heteroclitus, there have been few field studies of natural populations. Little is known about the less numerous and consequently less available species, such as Fundulus luciae, the spotfin killifish.

The scientific literature pertaining to Fundulus luciae consists mainly of collection records and laboratory studies of the genus Fundulus. Baird (1855) described the 
species from specimens collected at Beasely Point, New Jersey. It has subsequently been reported from Long Island to Georgia occupying shallow coastal waters associated with salt marshes (Smith 1892, Fowler 1912, 1914, 1927; Crawford 1920; Nichols and Breder 1927; Hildebrand and Schroeder 1928; Hildebrand 1941; Butner and Brattstrom 1960; Richards and Bailey 1967; Jorgens on 1969). The species has been included in generic studies of taxonomy (Brown 1954), karyology (Chen 1971), salinity tolerance (Griffith 1974) and erythrocyte morphology (Srivastava and Griffith 1974). The most comprehensive account of its biology, including stomach contents, reproductive season and egg size was given by Hildebrand and Schroeder (1928).

Several authors reported Fundulus 1uciae as rare (Hildebrand and Schroeder 1928; Richards and Bailey 1967). The discovery of a population in a marsh bordering the Ware River, Gloucester County, Virginia provided the impetus for a life history study of this purportedly rare species. A survey of marshes along the York River located other populations and one of these, in Fox Creek Marsh, was selected for study. Habitat characteristics, food habits, fecundity, spawning season, growth and development, behavior, species associations and parasites of this killifish are described herein. 
Study Area

Fox Creek Marsh (Figure 1) is located on the north bank of the York River, approximately $27 \mathrm{~km}$ from the mouth. Small freshwater streams drain into the marsh from surrounding woods. Brackish water from the York River flows in with every flood tide and is distributed throughout the marsh via a meandering network of large and small tidal creeks. Near the river, saltmarsh cordgrass (Spartina alterniflora) covers the marsh surface, extending from the main tidal creeks to steep wooded banks that delimit the marsh boundaries. Isolated stands of saltmeadow hay (Spartina patens), marsh elder (Iva frutescens) and groundsel tree (Baccharis halimifolia) are scattered within the profusion of cordgrass. This vegetation pattern extends upstream for about $1 \mathrm{~km}$ until cordgrass is eventually replaced by narrow-leaved cattail (Typha angustifolia). Within the cordgrass-cattail transition zone and along the marsh boundaries other plant species occur such as swamp rose mallow (Hibiscus moscheutos), seashore mallow Kosteletzkya virginica), smartweed (Polygonum lapathifolium), mock bishop's weed (Ptilimnium capillaceum) and saltmarsh

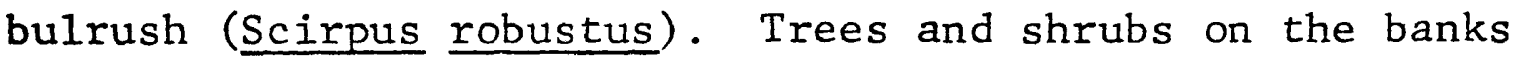
include red cedar (Juniperus virginiana), holly (Ilex opaca), mountain laure1 (Kalmia latifolia), red maple (Acer rubrum), 
spanish oak (Quercus digitata), swamp magnolia (Magnolia virginiana), wax myrtle (Myrica cerifera), tupelo (Nyssa sylvatica) and loblolly pine (Pinus taeda).

A localized concentration of Fundulus luciae was found amid the dense cordgrass growth in a high marsh area which was near both a wooded bank and the cordgrass-cattail transition zone. The locale possessed numerous puddles, water-filled mudholes and tidal rivulets in which Fundulus luciae occurred and from which all of the Fox Creek Marsh specimens were obtained. 
Figure 1. Map of the York River showing locations. where Fundulus luciae was collected: A, Ware River; B, Carmines Islands; C, Fox Creek Marsh; D, Roane Marsh; E, Yorktown Creek. The inset shows the location of the York River in relation to the Chesapeake Bay area. 


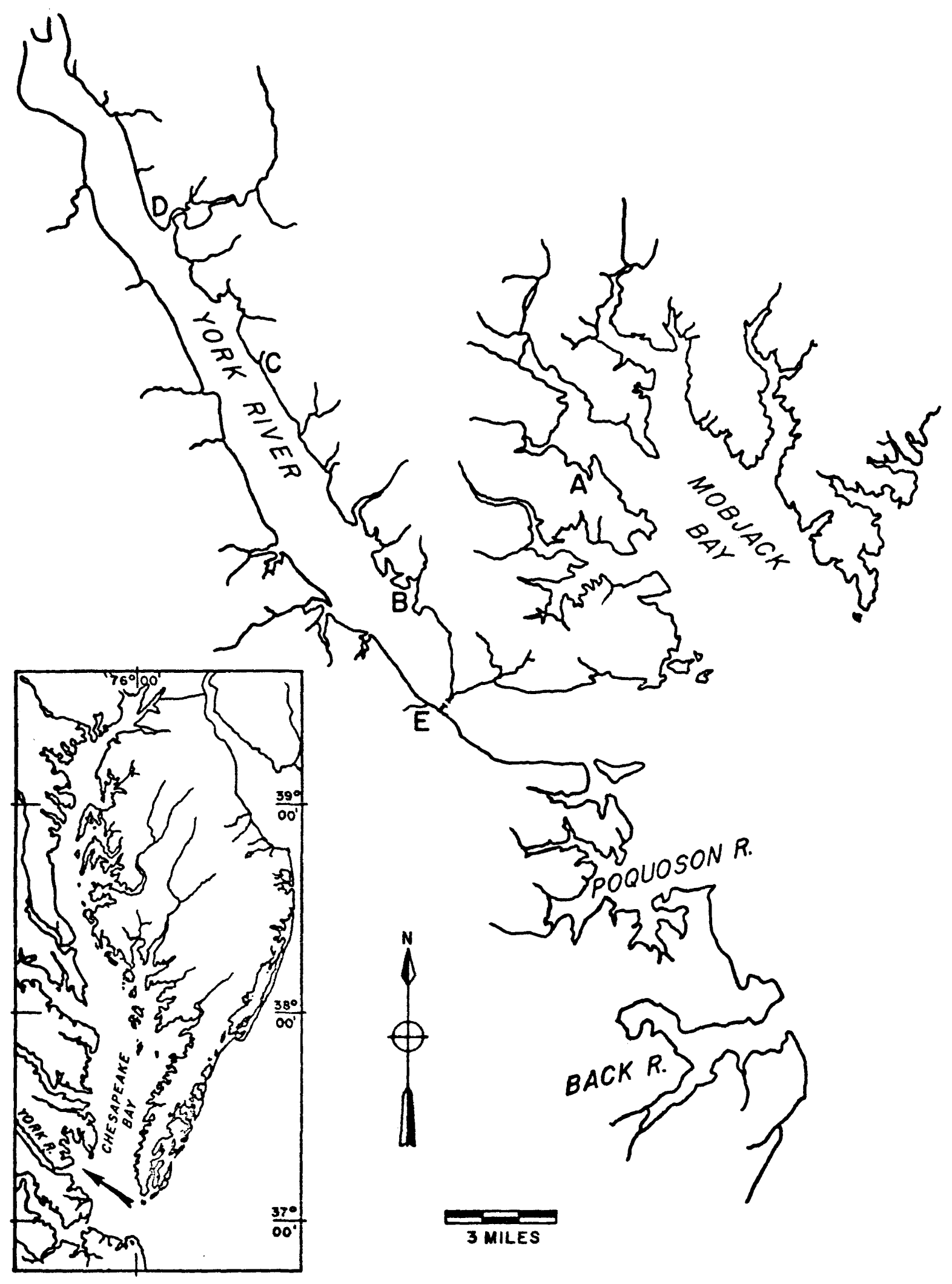


Methods and Materials

Adult Fundulus 1uciae were collected at Fox Creek Marsh with a dip net (38 cm diameter, $3 \mathrm{~mm}$ mesh) from 2 June 1973 through 8 July 1974. Two additional collections were made on $27 \mathrm{July}$ and 12 A.ugust 1975 to provide material from a sparsely represented time period. A total of 24 samples were collected during daylight hours at low water levels. Sample size was kept small to avoid depleting the population. At least five individuals of each sex were selected to obtain equal representation of the dimorphic sexes and variety in size. During cold weather fish appeared scarce and fewer were collected. Salinity and dissolved oxygen samples were taken in conjunction with each fish collection. Salinity was determined with a Beckman RS7B induction salinometer and dissolved oxygen by the Winkler titration method (Strickland and Parsons 1968). Water temperature was measured with a mercury stem thermometer.

Fish were preserved immediately after capture in $10 \%$ buffered formalin and stored for laboratory examination. Total length of each fish was recorded and a patch of scales from the scale rows above the lateral line, just anterior to the insertion of the dorsal fin, on the left side, were removed for aging. Scales were mounted on glass slides in Hoyer's medium (Humason 1972) and examined with both a 
microscope and scale projection machine for growth marks.

Observations of reproductive state, digestive tract contents and parasites were recorded from the preserved specimens. Male reproductive readiness was determined by the presence or absence of contact organs (Wiley and Collette 1970) and macroscopic appearance of the testes. Fecundity was measured by teasing the ovary apart and counting all eggs with a diameter $\geq 0.32 \mathrm{~mm}$. Eggs were measured with an ocular micrometer and grouped into three size categories: $0.32-0.96 \mathrm{~mm}, 0.97-1.6 \mathrm{~mm}$ and $>1.6 \mathrm{~mm}$. The digestive tract was excised and emptied upon a glass slide. Contents were identified and enumerated with microscopic examination. The fins, body surface, gills and viscera were examined for metazoan parasites. Each parasite encountered, except the monogenetic and digenetic trematodes, was identified to species if possible by the methods of Fernando et a1. (1972) and the keys of Cressey (1972), Hoffman (1967), Meehean (1940), Roberts (1970), Yamaguti (1961, 1963a, 1963b) and Yorke and Maplestone (1962). A few individuals of each morph of the abundant mono- and digenetic trematodes were selected as a subsample for identification.

Single collections were made at Ware Creek (4 March 1973), Roane Marsh (24 June 1973) and Yorktown Creek (30 June 1973). Specimens from these localities were treated in the same fashion as those from Fox Creek Marsh and data were combined for the respective time periods. 
Larval and juvenile Fundulus 1uciae were collected from Fox Creek Marsh with an aquarium dip net (0.35 mm mesh). Specimens were immediately preserved in $5 \%$ buffered formalin. Additional larvae were procured from eggs spawned in aquaria by captive adults. Newly hatched larvae were obtained by stripping and fertilizing eggs in plastic petri dishes. The eggs developed and hatched at room temperature in brackish water $(3.9 \%)$.

A total of 27 larval and juvenile fish, $5.3-17.0 \mathrm{~mm}$ in total length, were examined under a steroscopic dissection microscope to ascertain morphological changes associated with growth and development. Measurements of total length, standard length, depth, head length, eye diameter and snout length were made on the left side of each specimen with an ocular micrometer. Counts were made of vertebrae, branchiostegal rays and fin rays.

Reproductive and feeding behavior were observed in ten gallon aquaria filled with water of $0.1,3.9$ and $16.9 \%$ salinity. The aquaria were established 21 Apri1 1974 and maintained at ambient temperature and photoperiod until 9 June 1974. Each aquarium contained 2-3 spawning mops and up to 15 adult fish from Fox Creek Marsh, one-third of which were male. Each spawning mop was constructed of approximately $12020 \mathrm{~cm}$ long strands of green acrylic yarn bound together and anchored with a clean oyster shell in the sand covering the tank bottom. The mops were periodically examined for eggs. Those discovered were 
removed to plastic petri dishes for development and hatching. The dishes were kept at room temperature and contained water from the tank in which the eggs had been spawned. Adult fish were fed bread crumbs, chopped frozen shrimp and chopped live earthworms. Water was filtered and aerated by a plastic filter box within the tank. 


\section{Results}

\section{Habitat}

The habitat occupied by Fundulus 1uciae was similar at al1 localities and included water-filled mudholes, narrow ditches, small pools and tidal rivulets with soft muddetritus bottoms. These areas were usually situated among dense stands of Spartina alterniflora and contained shallow water, seldom deeper than $0.5 \mathrm{~m}$ and frequently only a few centimeters deep, except during high spring or storm tides. Fish were occasionally observed partially emerged, wriggling from one puddle to another through water less than $1 \mathrm{~cm}$ in depth. The edges of these shallow water bodies consisted of firm mud from which tangled mats of Spartina roots often protruded. Cave-like indentations occurred where the marsh had been undercut and partially submerged wads of decaying vegetation were present. These features and the soft bottom provided cover for the fish, which would dart into them and hide when disturbed.

Water depth at the Fox Creek Marsh collection site was dependent on tide height. High spring and storm tides inundated the marsh, including the area where $F$. 1uciae was concentrated. A futile collection attempt was made on one such occasion and specimens were not captured in the usual 
ditches and mudholes until the water had subsided. Apparently the fish dispersed over the flooded marsh surface. Opportunities to disperse were limited because not all high tides submerged the high marsh. Some produced only slight increases in depth and others had no effect whatever. Water currents and salinity at Fox Creek Marsh were also tidally influenced. In the absence of marsh-inundating tides, freshwater flowed continuously, but weakly, through the F. Iuciae habitat and diluted the brackish water. The lowest salinity recorded was $0.2^{\circ}$ and values less than $1^{\text {to }}$ were common. When high tides flooded the marsh, strong currents were created in the ditches and rivulets by the ensuing ebb. Such tides were also accompanied by increases in salinity. The highest salinity recorded was $12.7 \mathrm{c}$.

Water temperature and dissolved oxygen at Fox Creek Marsh were extremely variable throughout the year. Water temperature ranged from 4 to $36^{\circ} \mathrm{C}$. Ice formed during winter cold spells, but was not long-lasting and was seldom thicker than a few millimeters. Dissolved oxygen ranged from less than 1 to $6.8 \mathrm{mg} / 1$.

F. luciae was present at the Fox Creek Marsh collection site throughout the year despite the rigorous environmental conditions. It appeared most abundant in spring and summer, when small groups of fish were constantly observed cruising and darting through the water. At such times many fish were easily captured with a few sweeps of the dip net. During cold, overcast weather, however, these groups were 
not observed. Specimens were collected only by sampling in undercuts, decaying vegetation and bottom substrate, which yielded few individuals. During winter warm spells swimming fish reappeared, but on $1 y$ in a fraction of their spring and summer abundance.

Species Associations

Four other species of fishes were captured in areas where F. Iuciae was present. These were the mummichog (Fundulus heteroclitus), the sheepshead minnow (Cyprinodon variegatus), the rainwater killifish (Lucania parva) and the mosquitofish (Gambusia affinis). G. affinis and L. parva were both rare in F. luciae habitats. The former was captured only at Fox Creek Marsh and the latter only at Ware River and Roane Marsh. F. heteroclitus and $\mathrm{C}$. variegatus were relatively common at all locations. At Fox Creek Marsh $\underline{C}$. variegatus was taken infrequently, but adult and juvenile $\mathrm{F}$. heteroclitus were abundant and frequently outnumbered F. luciae in samples.

\section{Male Reproductive Cycle}

Male sexual maturity was attained at a total length of 24-27 $\mathrm{mm}$ and was signalled by a change in coloration. Prior to maturation males were indistinguishable from the plain grayish-green females. At maturity, 10-14 dark vertical bars formed along the sides and a black ocellus appeared on the posterior rays of the dorsal fin. Further 
changes in coloration were associated with reproductive activity: the vertical bars and ocellus became intensified and the belly, pelvic and anal fins, lower caudal peduncle and caudal fin became yellowish-orange.

Contact organs were present on three areas of breeding males: the sides, head and medial fins. They resembled fleshy papillae with single short terminal bristles and were visible only under magnification. Those on the sides were represented by a single papilla on the posterior tip of each scale. On most males contact organs extended longitudinally from just behind the pelvic fin base to the anterior edge of the caudal peduncle and dorso-ventrally over the entire side, excluding the top three and bottom two scale rows. Head papillae were smaller than those on the sides and were generally confined to the cheek and lower opercle. They seemed randomly scattered and were not associated with scales. Papillae on the dorsal and anal fins were as large as those on the sides and originated from fin rays. They were clustered near the margin of each fin, with few or none near the base. Individual differences existed in the exact number and location of papillae, but in general they followed the distribution described (Figure 2).

Contact organs were present on 130 of 131 adult males collected from March through August and were absent on 36 males collected from September through February, parallelling the temporal pattern of testicular development. 
Figure 2. Distribution of contact organs on an adult male Fundulus luciae. Each mark represents one contact organ. 


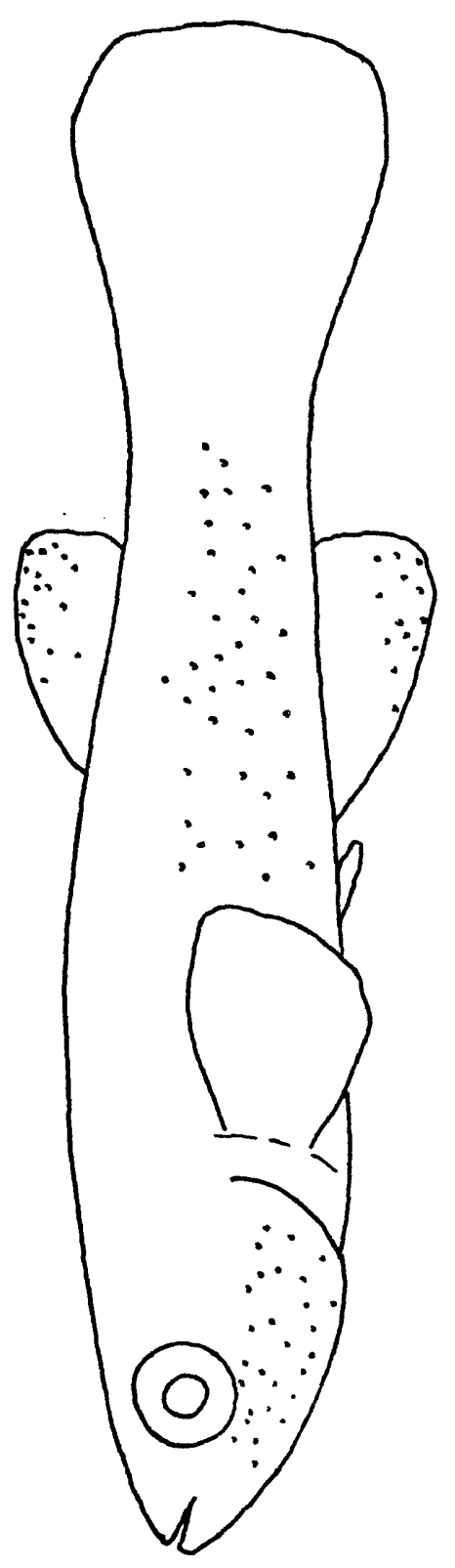


Female Reproductive Cycle

Females attained sexual maturity at a total length of 28-30 mm. Maturity was not marked by any change in coloration and secondary sex characteristics were not evident during the spawning season. Both adult and juvenile females were grayish-green, with a few possessing numerous, faint, vertical bars along the sides.

Spawning season was indicated by the presence of mature and incipient mature ova ( $>1.6 \mathrm{~mm}$ diameter) in ovaries of adult females and extended from mid-April to mid-August. During this period ovaries contained eggs exhibiting a continuous gradation of size (Table 1). Egg size and egg frequency displayed an inverse relationship. The number of eggs $>1.6 \mathrm{~mm}$ varied sporadically among samples, suggesting discontinuous and perhaps synchronous spawning (Table 2). Their frequency in a sample, however, did not correspond with any lunar or tidal phase.

Mature eggs (about $2 \mathrm{~mm}$ diameter) were demersal, spherical to slightly elliptical and were characterized by a polar aggregate of oil globules and papillary ornamentation of the chorion (Figure 3). Adhesive gelatinous threads were evident on most freshly stripped or spawned eggs. Measurements of egg size and oil globule number were made on 40 fertilized eggs (Table 3). 


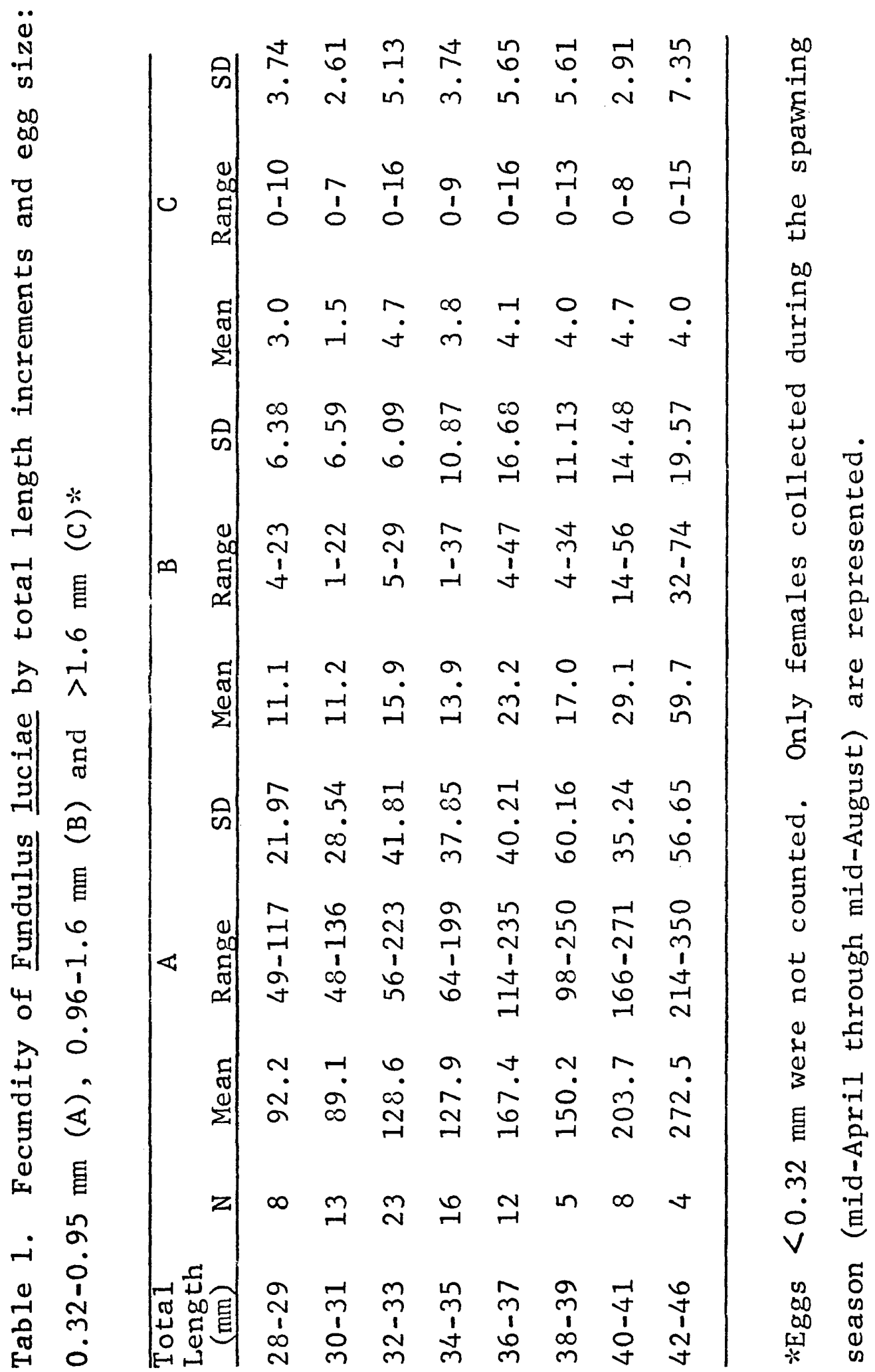




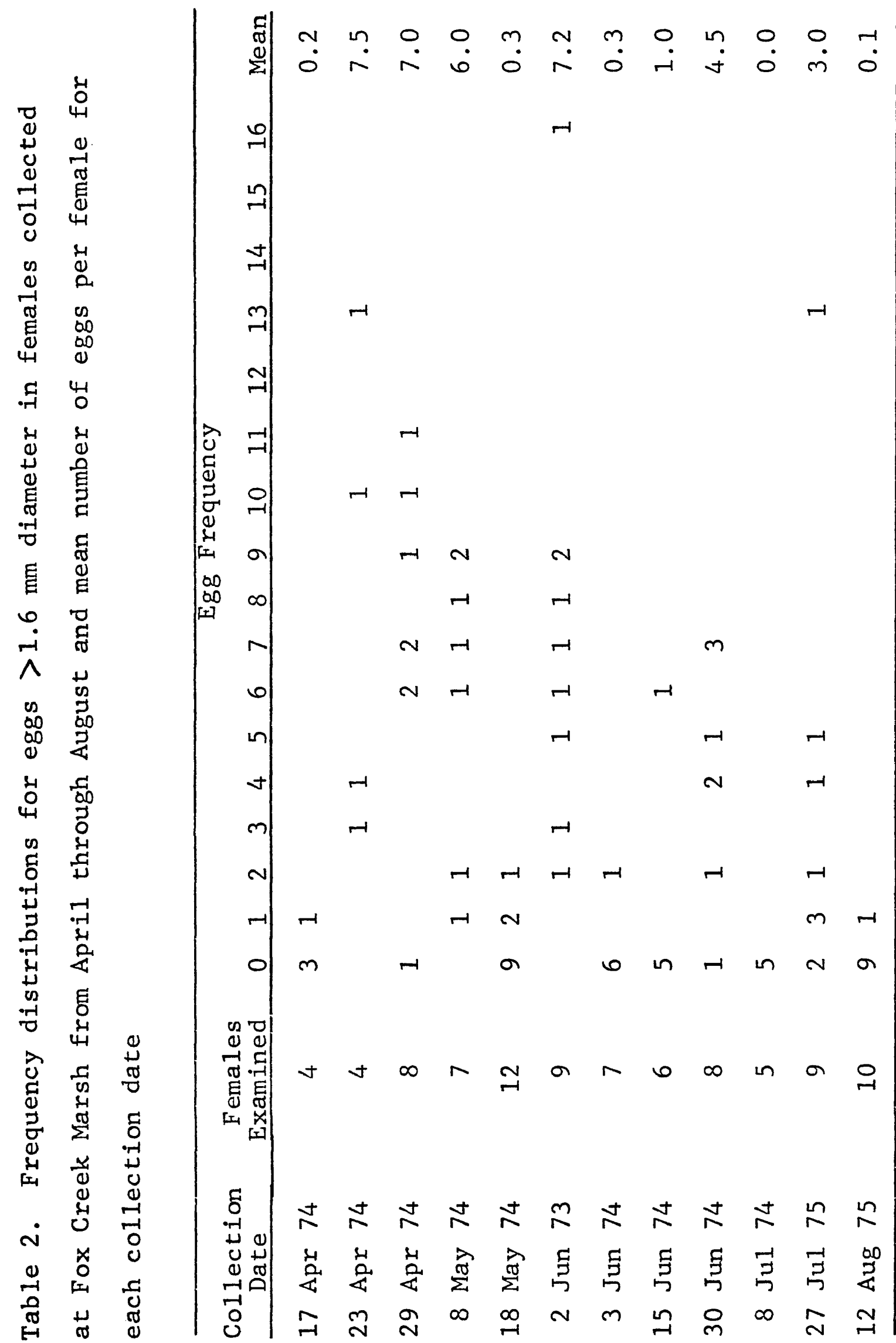

$\stackrel{\infty}{\sim}$ 
Table 3. Variation in the diameter and number of oil globules per egg of 40 fertilized Fundulus luciae eggs

\begin{tabular}{|c|c|c|}
\hline Character & Statistic & Value \\
\hline \multirow{3}{*}{ Egg Diameter (mm) } & Mean & 1.96 \\
\hline & Range & $1.76-2.18$ \\
\hline & SD & 0.10 \\
\hline \multirow{3}{*}{ Oil Globules per Egg } & Mean & 21.8 \\
\hline & Range & $5-58$ \\
\hline & SD & 13.35 \\
\hline
\end{tabular}


Figure 3. Mature unfertilized ovum, $1.92 \mathrm{~mm}$ in diameter, - of Fundulus luciae showing the characteristic aggregate of oil globules and minute papillary ornamentation of the chorion. 


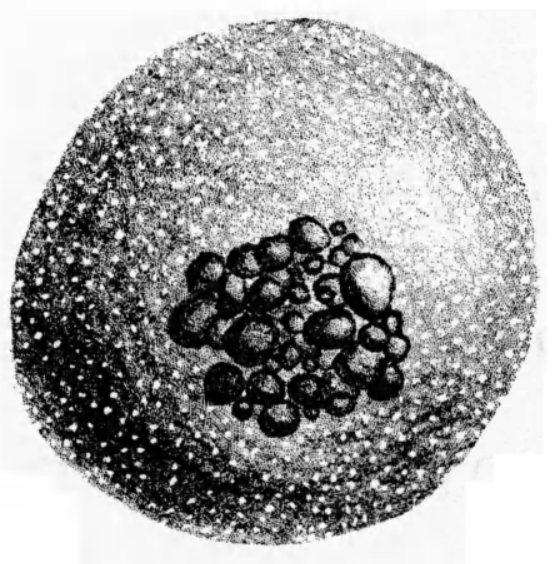


Spawning Behavior

Spawning behavior was observed on three occasions: twice in aquaria (29 April 1974, 20 May 1974) and once at Fox Creek Marsh (23 April 1974). The behavior observed was similar on all three dates and may be divided into three sequences: approach, pursuit and spawning act.

Approach involved the movement of a male toward a slowswimming or stationary female. The male's approach was usually made in the same plane as the female and from either side or behind, but never head-on. The female usually responded by swimming a short distance away, but if she did not, subsequent concact with the male, consisting of a slight brush or gentle butt, always prompted her to do so. The male then either ignored her or repeated his actions, with the same result. A male would often make several approaches before finally losing interest, but persistence usually elicited pursuit behavior. Short retreats by the female became longer and longer, with the male rapidly following, until eventually both began swimming side by side for intervals of about 15 seconds.

The side by side swimming characteristic of the pursuit sequence was punctuated by short pauses of 5-10 sec. duration. During these the male often rubbed and butted his head and body on the head, sides and belly of the female. Such actions usually resulted in the resumption of vigorous swimming. While swimming, the male followed the female very closely. He was usually positioned directly alongside, with 
his eye opposite the female's operculum. Occasionally, while in this position, his medial fins were momentarily bent toward and around the female's body. This was performed from either the right or left side.

Pursuit behavior eventually culminated in the spawning act. The spawning act was only observed once, in an aquarium. After 60 minutes of pursuit behavior a male cornered a female between the filter, which obscured the act, and the glass wall of the tank. One egg was produced and was suspended between the glass wall and filter by clear, adherent threads. After this the male continued to approach the same female, but his attention was more often directed toward other females in the aquarium.

Male territorial behavior was centered around females being courted. Agonistic behavior was sometimes observed between two males pursuing the same female. It consisted of movement by one male toward the other, often with an attempted nip, and resulted in the flight of the male being threatened. Males were promiscuous and frequently switched their attention from one female to another. The initiative usually resided with the male. A female once approached and butted a male, but elicited no response. During spawning activity the side bars, ocellus and yellowishorange underparts of the male were vivid, but the drab grayish-green of the female remained unchanged. 
Spawning Conditions and Sites

Spawning occurred in aquaria containing water of 0.1 , 3.9 and $16.9 \%$ at temperatures of $20-25^{\circ} \mathrm{C}$ and exposed to natural photoperiods of 13-1/2 to 15-1/4 hours. Eggs were deposited on spawning mops, where they firmly adhered to strands of yarn. Eggs occurred throughout each mop, individually and in clusters of two to four. Most were solitary and located at or near the base of the mop, where the strands were densest. Eggs were not found elsewhere in the tanks and the instance of one being spawned between the filter and tank wall was exceptional.

During the spawning season at Fox Creek Marsh (midApril to mid-August) water temperatures of $19-36^{\circ} \mathrm{C}$, salinities of $0.2-9.1 \%$, dissolved oxygens of $<1-6.8 \mathrm{mg} / 1$ and photoperiods of $13-1 / 2-15-1 / 3$ hours were recorded. Spawning mops were placed in areas occupied by Fundulus luciae, but no eggs were found on them. Eggs were not found on natural substrates.

Development and Growth

The length of the embryonic period of Fundulus luciae seemed to be influenced by salinity. Eggs kept in fresh $(0.1 \%)$ and brackish (3.9\%) water at $20-25^{\circ} \mathrm{C}$ usually hatched in 12-16 days, but some, including most eggs in 16.9\%, hatched much later. One egg in 16.9\% hatched only after 43 days and 13 after 33 days. These latent embryos were more developed at the time of emergence than those 
emerging after a 12-16 day embryonic period. The latter were 5.3-6.0 $\mathrm{mm}$ in total length, possessed large yolk sacs and rayless ventral finfolds. In contrast, latent embryos were larger (6.0-6.3 $\mathrm{mm}$ in total length) and possessed very reduced yolk sacs and ventral finfolds with partially formed anal rays.

A yolk-sac larva which hatched at 14 days was preserved and is depicted in Figure 4A. The caudal fin contained 12 rays and was confluent with the unpigmented, rayless finfolds. The dorsal finfold terminated between the 17 th and 18 th neural spines (counting forward from the caudal fin) and the ventral finfold extended to the posterior edge of the yolk sac. The yolk sac was relatively large, with a welldeveloped network of vitelline vessels, and oil globules were dispersed about its surface. The pectoral fins contained partially formed rays. The head possessed a terminal, toothless, non-protractile mouth, a very short snout (16.5 in head), we11-formed eyes and five branchiostegal rays. A pair of otoliths, the larger about three times the size of the smaller, were located slightly posterior to each eye. The otoliths were not stationary and changed position when the specimen was manipulated. The vertebra1 column consisted of 31 vertebrae. Numerous sma11 melanophores were present on the dorsal surface of the head and back, along the finfold bases and over the yolk sac, especially the dorsal portion. A few were also present on the lateral aspects of the head. 
The first morphological changes were noted in larvae of 6-7 mm TL (TL = total length) $($ Figure $4 \mathrm{~B})$. Specimens of this size no longer possessed a yolk sac and a S-shaped alimentary tract was visible beneath the unpigmented walls of the visceral cavity. The mouth had become protractile and slightly upturned, with the lower jaw protruding slightly in front of the upper. Villiform teeth were present along the forward edge of each jaw. Fin ray development had commenced in the ventral and dorsal finfolds, with the appearance of rays in the former preceding the latter. The caudal fin rays had increased to $16-20$, but the pectoral fin rays were still only partially formed. Also, the lateral line was now discernible.

Subsequent development consisted primarily of fin ray formation, squamation and pigmentation (Figures $4 \mathrm{C}$ and 4D). Further changes were not observed in the mouth or alimentary tract, other than size increase. Otoliths remained visible in larvae as large as $9 \mathrm{~mm} \mathrm{TL}$, but increased opacity of the head obscured them in larger individuals. Increased opacity of the anterior dorsal musculature precluded vertebral counts of specimens larger than $9 \mathrm{~mm}$ TL. Vertebral counts of smaller larvae ranged between 31 and 33 , the adult complement. All specimens, regardless of size, possessed at least five branchiostegal rays and a few, larger than 8 $\mathrm{mm} \mathrm{TL}$, possessed a short, innermost sixth ray.

A11 fins were completely formed on specimens larger than $13 \mathrm{~mm}$ TL. Although considerable individual variation 
existed, the caudal fin was generally completed first, followed by the anal, dorsal, pectorals and, finally, pelvic fins. Medial fin development involved the elevation of the finfolds in areas of ray formation and their gradual descent elsewhere. Finfold vestiges were present on larvae of 11-12 $\mathrm{mm}$ TL, but were absent from larger individuals. The number of rays present in the various fins at different total lengths is listed in Table 4.

The pigmentation pattern of the yolk-sac larva remained essentially unchanged in larger individuals prior to squamation. Some melanophores appeared adjacent to fin rays and near the finfold bases and dorsal portion of the visceral cavity. The belly and sides of the body, however, remained unpigmented.

Squamation was first observed on larvae of 10-11 mm TL. Scales arose on the sides first, then the back, head and finally the belly. Specimens exhibiting squamation also displayed melanophores in previously unpigmented areas. Squamation and pigmentation were complete on individuals of 11-13 mm TL, except for the belly, which was complete on specimens of $17 \mathrm{~mm}$ TL and larger.

Changes in body proportions during development were gradual and subtle. They are summarized in Table 4.

At Fox Creek Marsh, larvae of Fundulus 1uciae and Fundulus heteroclitus occurred together and were very similar in appearance. The smallest specimens could be distinguished, however, by the dorsal pigmentation pattern 
of the head and back (Figure 5). On F. luciae this pattern consisted of many sma11, dark, evenly distributed melanophores. The melanophores on F. heteroclitus, by comparison, appeared less numerous, larger and blotchy, especially over the head. In addition, specimens of $\mathrm{F}$. heteroclitus with we11-developed dorsal fins possessed a spot at the base of the first dorsal ray. This spot, a dense aggregation of melanophores, was not present in $\underline{F}$. luciae. The mid-dorsal stripe of F. luciae, a field mark useful in distinguishing it from other cyprinodonts (Richards and Bailey 1967), was not present in specimens less than $11 \mathrm{~mm}$ TL.

The maximum size attained by Fundulus luciae is approximately $40 \mathrm{~mm}$ standard length, which makes it the smallest species in the genus Fundulus (Rosen 1973). In the present study the largest male and female collected were respectively 40 and $47 \mathrm{~mm}$ TL. Most males, however, ranged between 28-35 mm TL and most females ranged between 30-40 $\mathrm{mm}$ TL. A short life span is indicated by the small size attained by the species. Scales examined for age determination in some instances possessed a single indistinct annulus. Usually annuli could not be discerned. It seems unlikely that individuals survive much longer than one year. 
Figure 4. Fundulus 1uciae larvae at different stages of development: A, $5.3 \mathrm{~mm} \mathrm{TL} ; \mathrm{B}, 6.2 \mathrm{~mm}$ TL; C, $9.5 \mathrm{~mm} \mathrm{TL}$; D, $11.2 \mathrm{~mm}$ TL. 

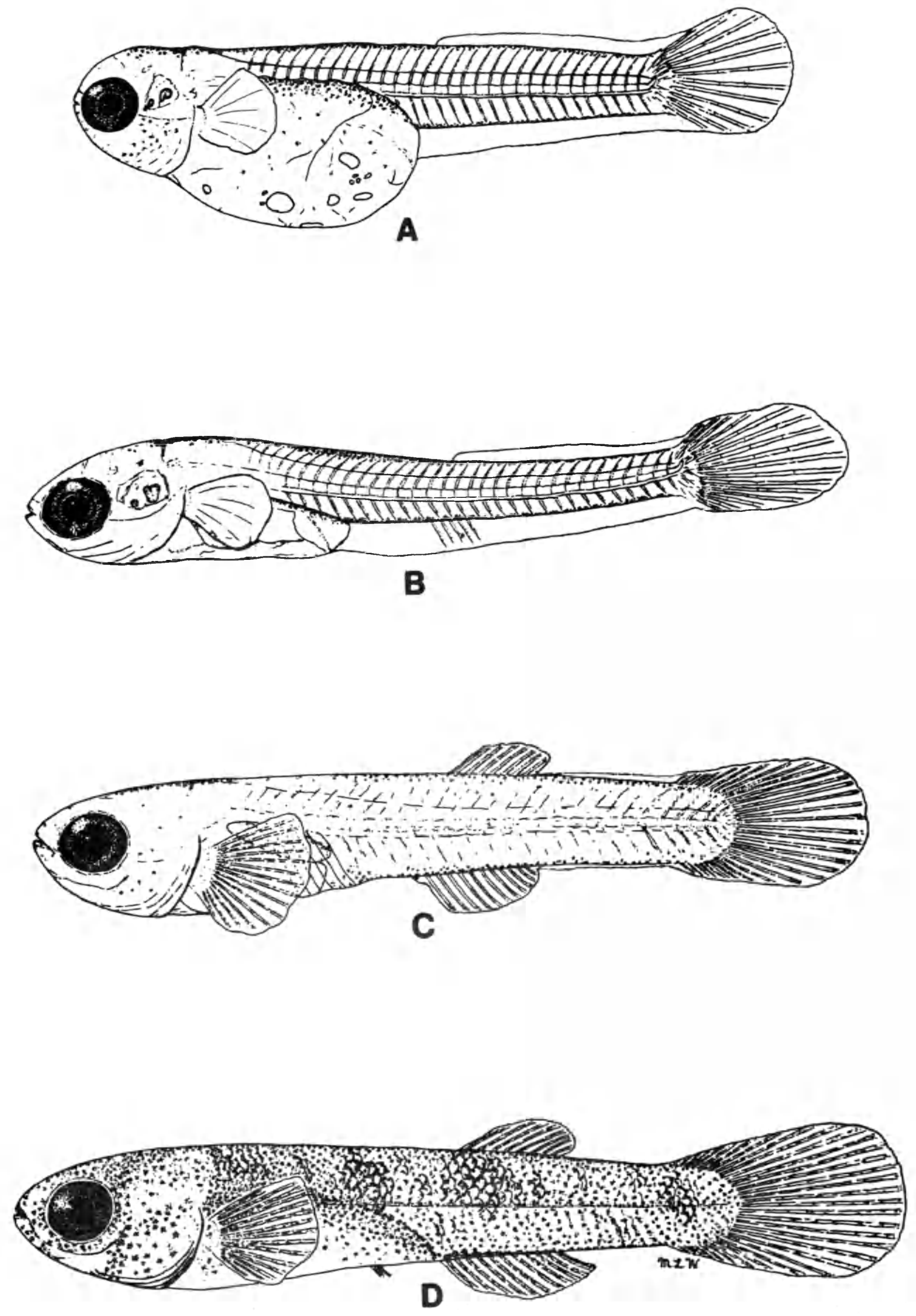


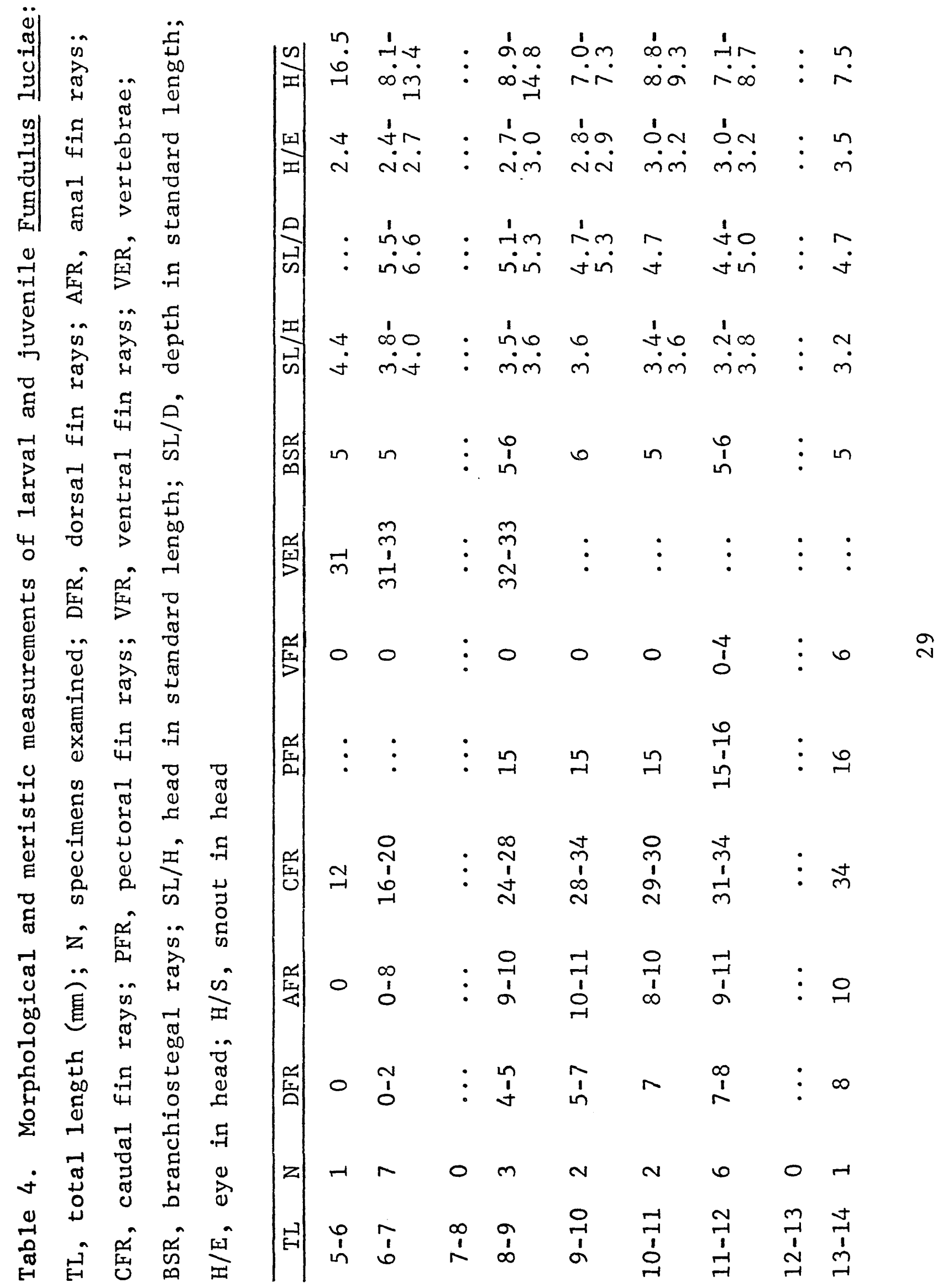




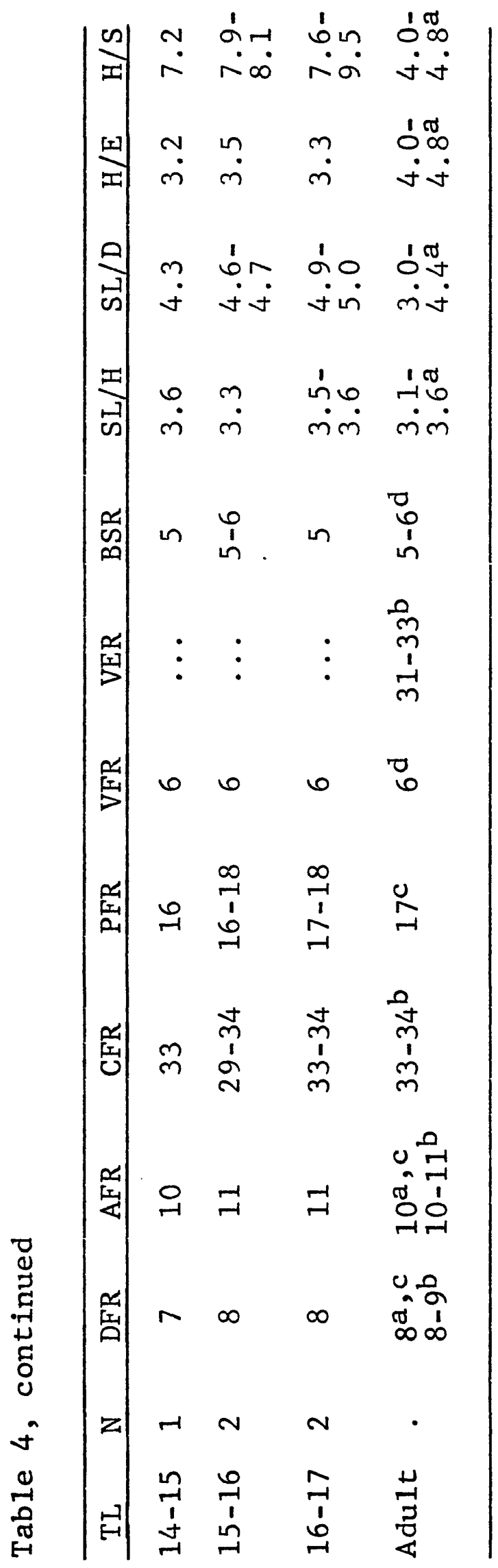

n

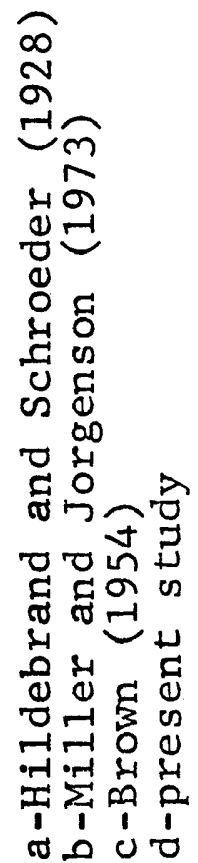


Figure 5. Dorsal pigmentation patterns of Fundulus heteroclitus (A) and F. luciae (B) larvae. F. luciae is characterized by a homogeneous pattern of small dense melanophores. F. heteroclitus possesses large splotchy melanophores and a spot near the base of the first dorsal ray. 

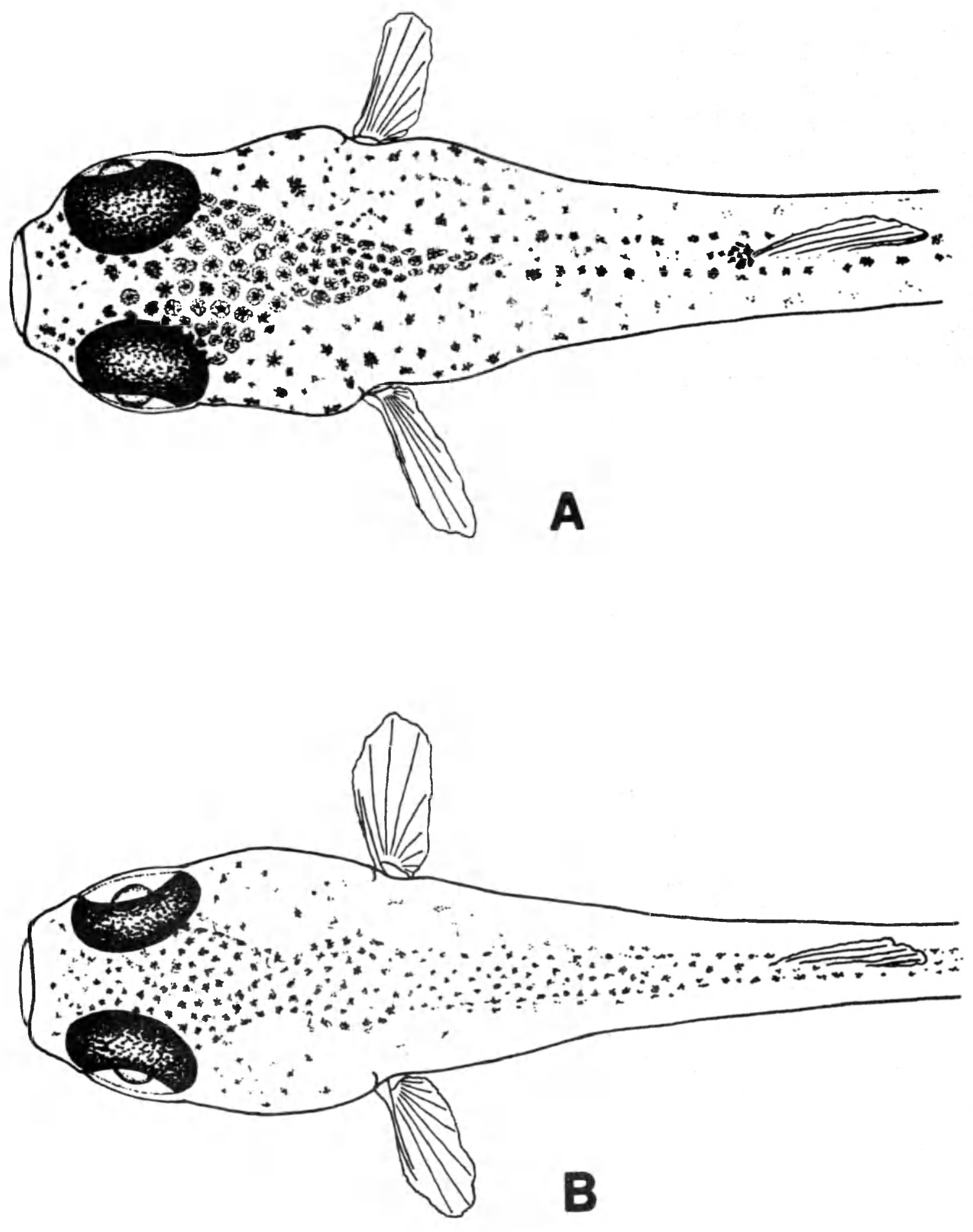
Diet

Analysis of digestive tract contents showed Fundulus luciae is omnivorous (Table 5). The principal items ingested included detritus, diatoms, ostracods, dipterans (mainly mosquitoes and chironomid larvae) and copepods. A variety of other items, primarily aquatic and terrestrial arthropods, were also eaten.

The small sample sizes of late autumn and winter prevent accurate representation of seasonal diet trends, but seasonal peaks and depressions are discernible for some food items. For example, detritus and diatoms were present in most specimens throughout the year, except August and September ( and November for diatoms). Homopterans exhibited the converse of this pattern. Such variation is probably the result of differences in food availability and selection preferences.

Feeding behavior was observed in aquaria, in a shallow outdoor wading pool and at Fox Creek Marsh. Vision seemed important in locating food items. At Fors Creek Marsh, slowly swimming fish were observed to stop suddenly, stare intently at the substrate before them and, after a few moments, dart forward and nip at it. Individuals confined in an outdoor wading pool jumped out of the water to capture small homopterans resting on the sides, just above the surface. Homopterans not immediately captured were frequently knocked onto the surface and subsequently ingested. Jumping was elicited from aquarium-held fish by 


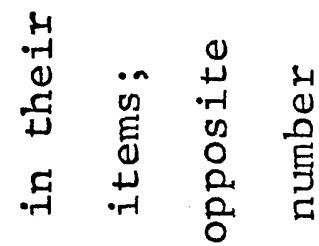

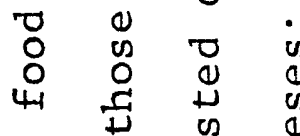

.

.

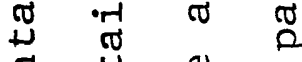

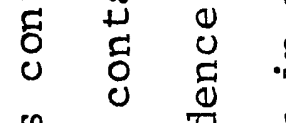

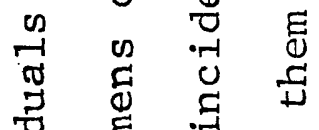

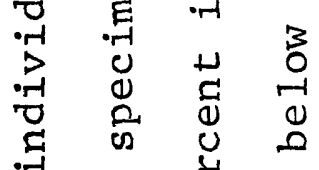

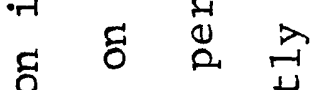

$7 \quad 0 \quad 4 \quad 0$

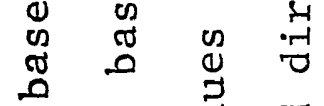

a

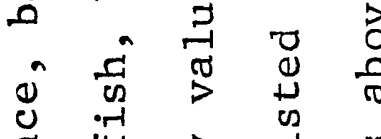

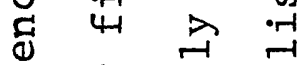

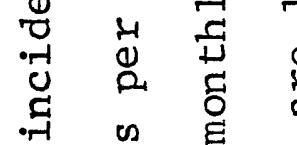

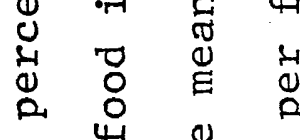

मी सु

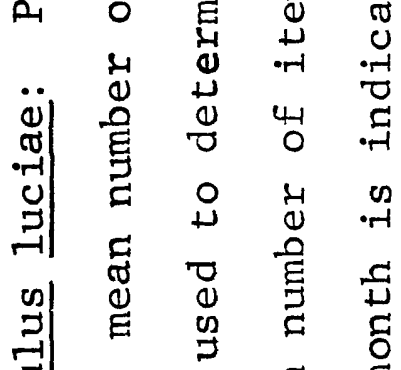

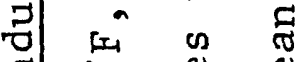

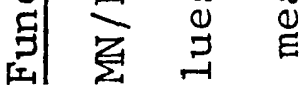

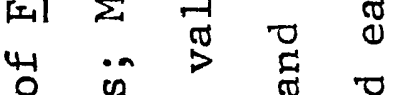

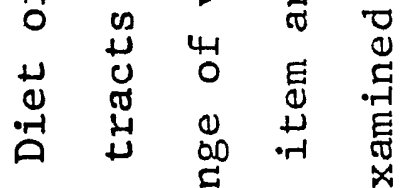

$\therefore \stackrel{\infty}{3} \stackrel{5}{3}$

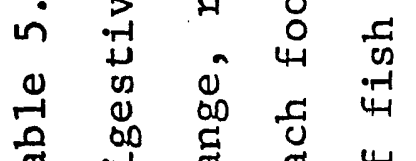

mo $\because r ก \overparen{n}$

ن

No

-

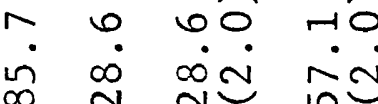

$\infty$ v $\stackrel{\sim}{*}$ กิบ

Fu

๑ $\sigma \widehat{T}$

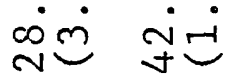

0 moิ

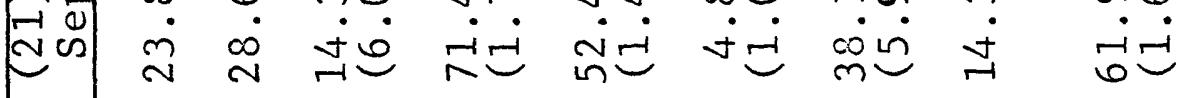

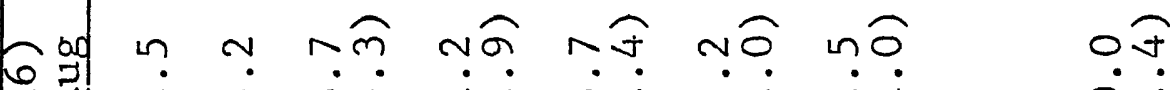

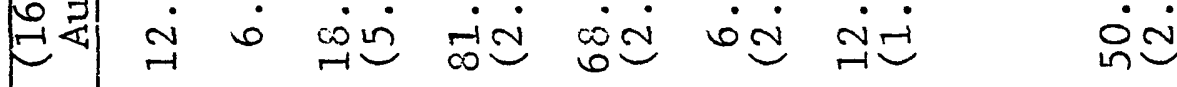

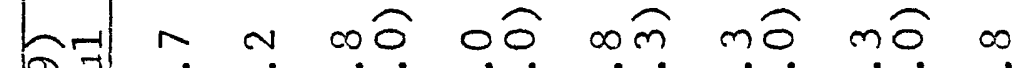

செ

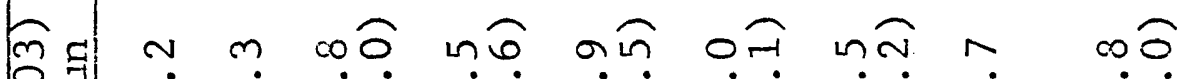

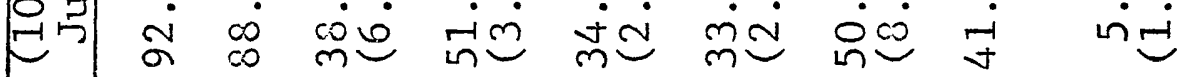

6) $v$ v

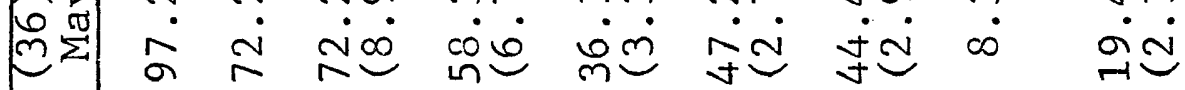

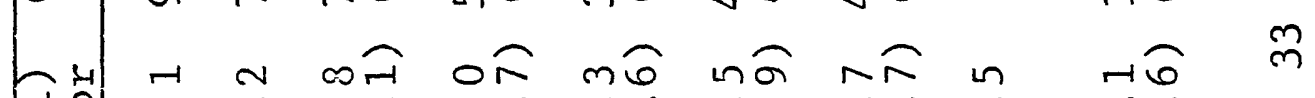

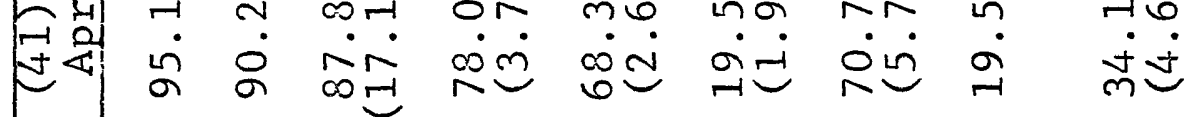

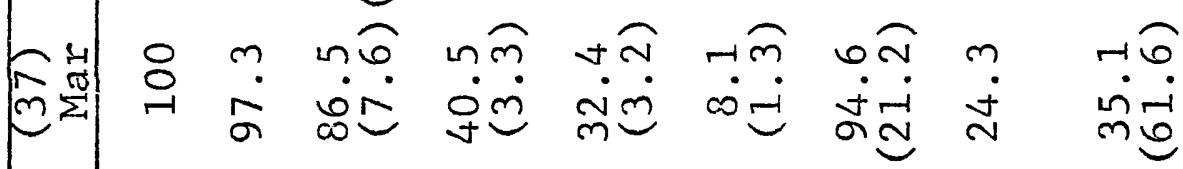

60 m $\because$.

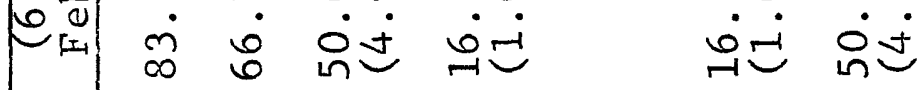

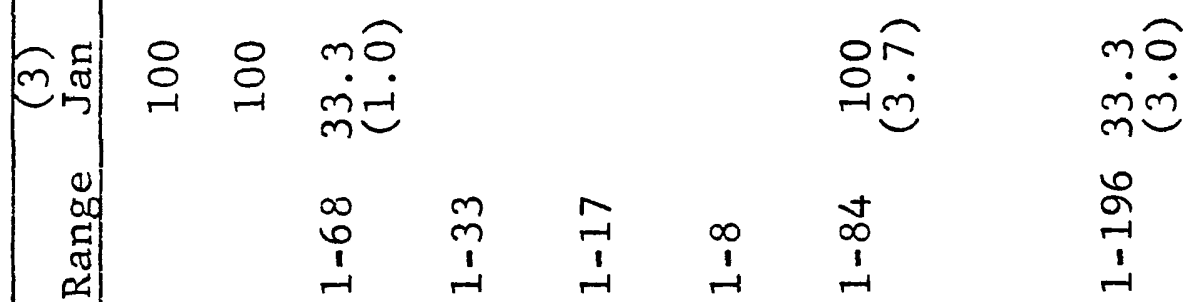

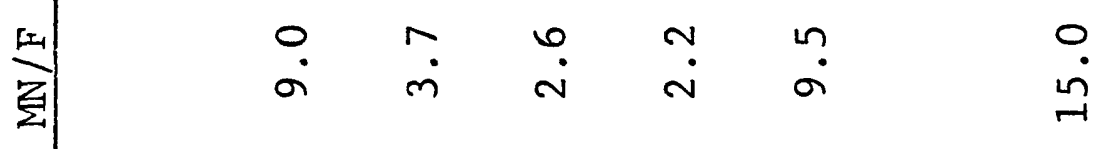

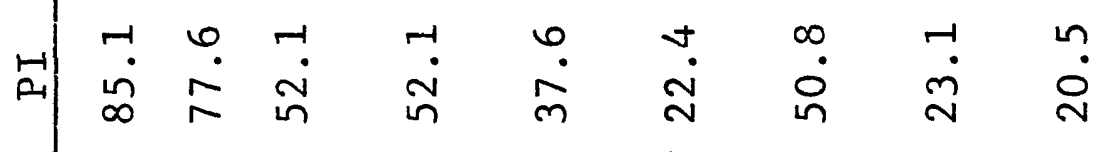




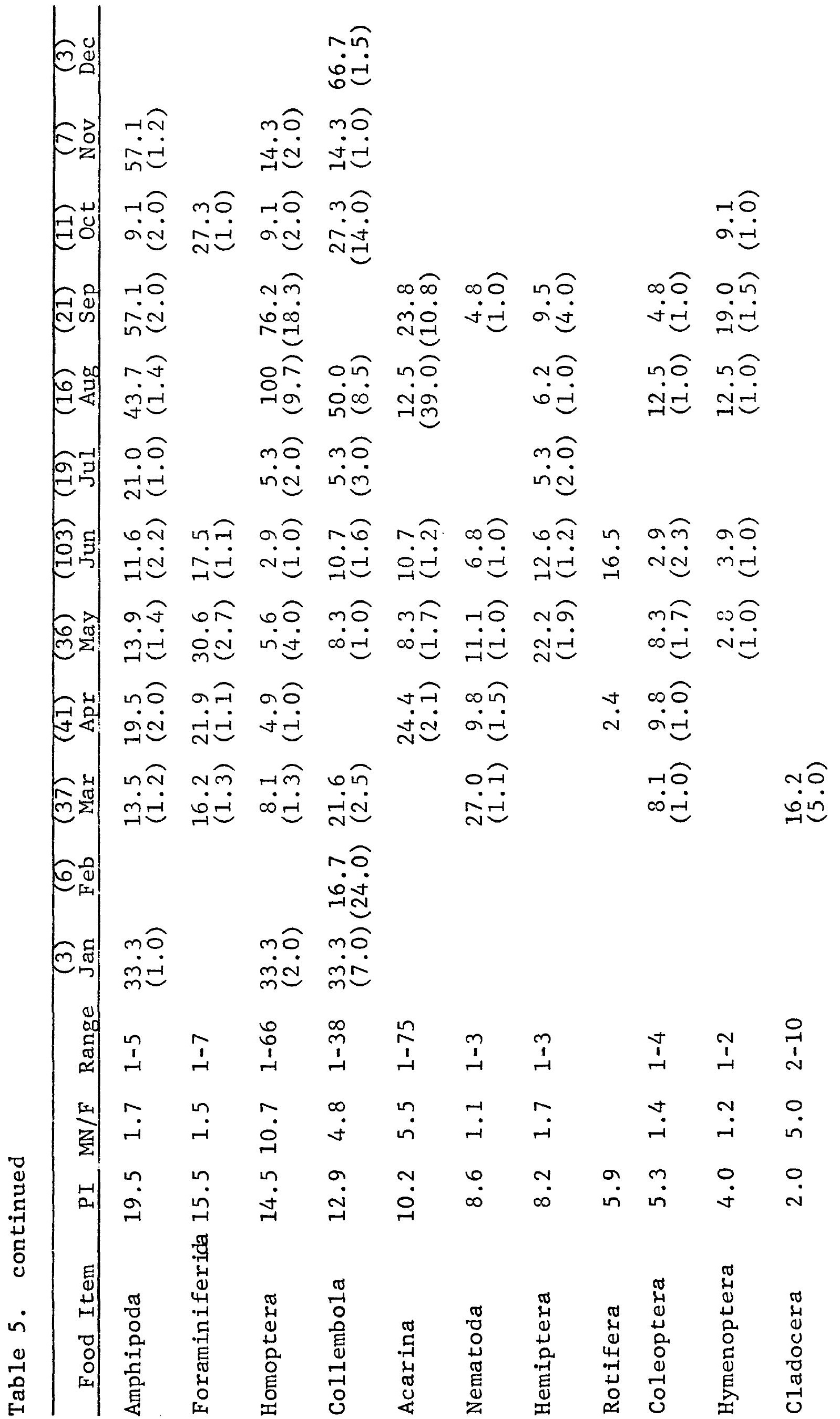




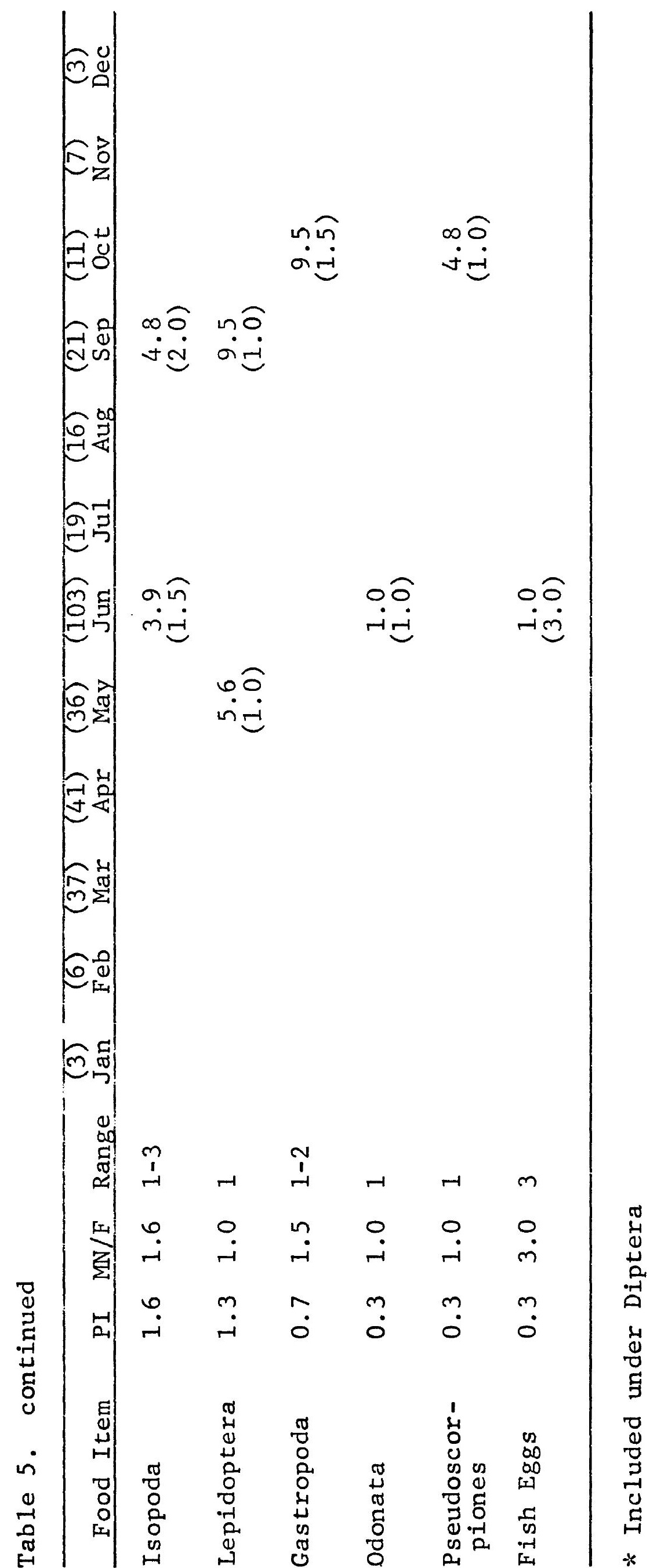

n 
sticking pieces of earthworm to the aquarium glass near the surface of the water. Fish $30-40 \mathrm{~mm}$ TL successfully reached worm segments as high as $26 \mathrm{~mm}$. Aquarium-held fish also consumed items floating on the surface, sinking through the water and resting on the bottom. Particles too large for complete ingestion were sometimes grasped between the jaws and shaken vigorously. A fragment small enough for consumption was occasionally removed by this action.

\section{Parasites}

Representatives of every major metazoan parasite group, except Cestoda, occurred on Fundulus luciae (Table 6). Some parasites, because of their minute size and the lack of live material, may not have been detected. Trematode abundance is, at best, a minimum estimate. Monogenea and Digenea respectively constituted the most numerous and most consistently present groups.

The organs most frequently parasitized were the gills (Monogenea and Copepoda), alimentary tract (Digenea) and liver (Acanthocephala and Nematoda) (Table 7). Except for the monogenetic trematodes and copepods, most parasites were immature, encysted forms. Parasitized fish exhibited no gross external morphological deformities except for those individuals containing large specimens of Eustrongyloides $\mathrm{sp}$. These nematodes were frequently more than $60 \mathrm{~mm}$ long and occupied considerable volume within the visceral cavity, where they were coiled in cysts. Fish containing them possessed distended bellies. 


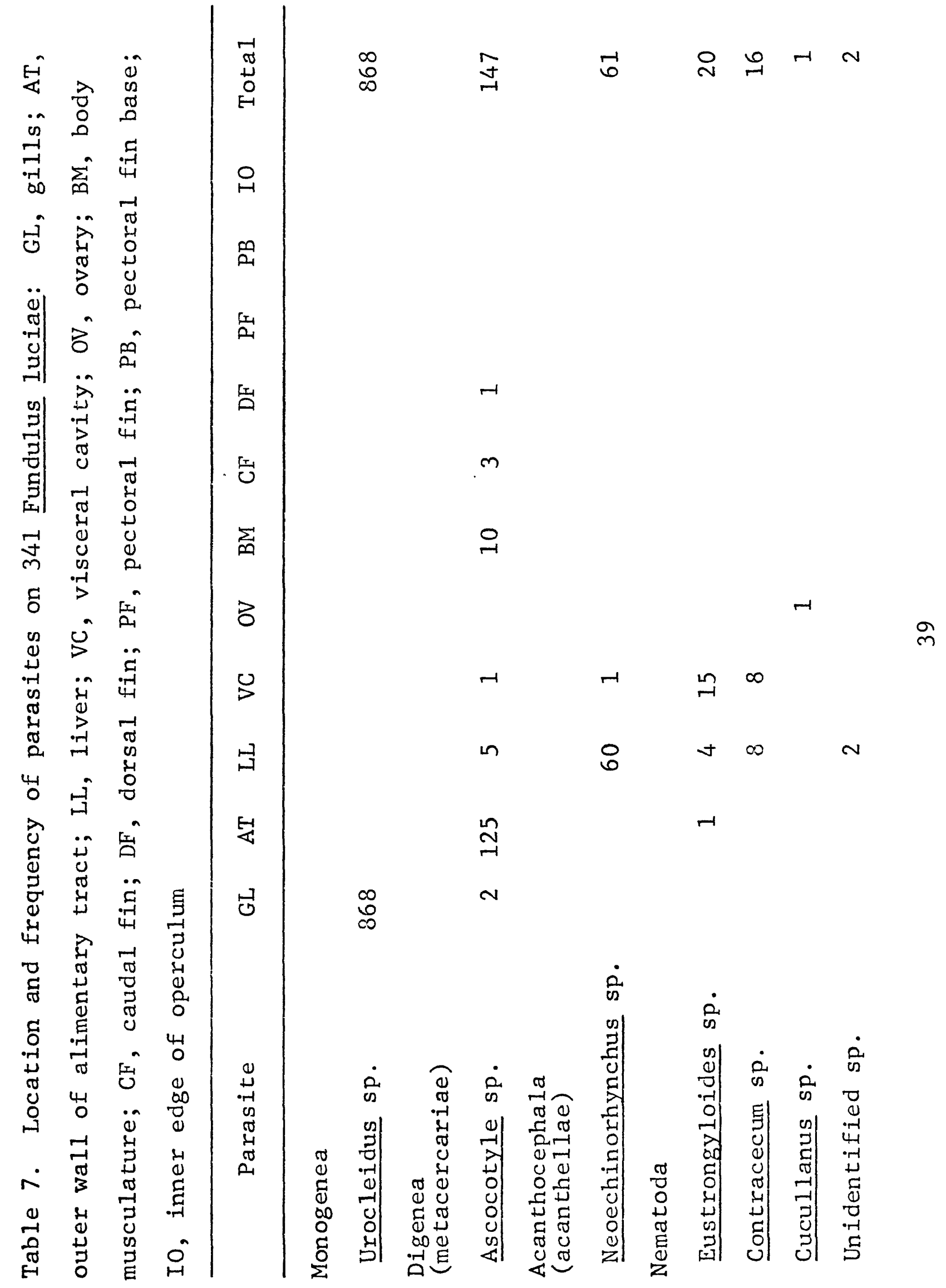




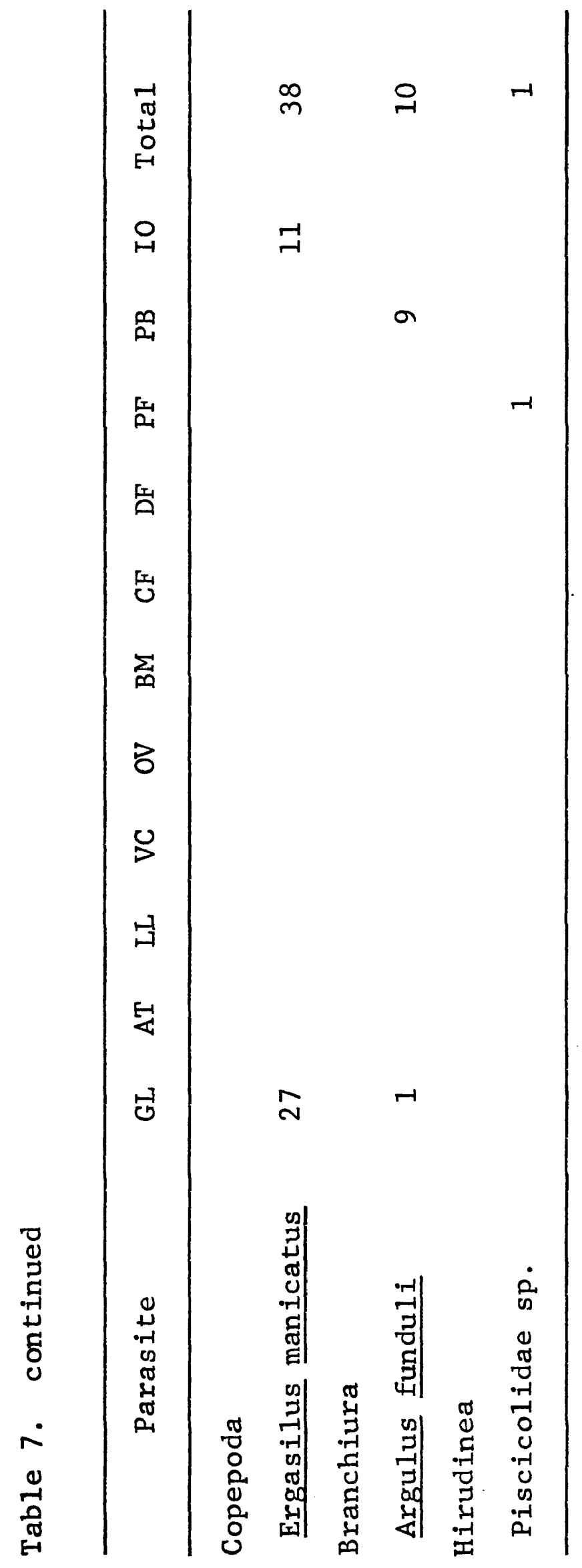

$\stackrel{9}{+}$ 
Hybridization

Three Fundulus luciae eggs were stripped and successfully fertilized by spermatozoa from Fundulus heteroclitus. The reciprocal cross, involving $11 \mathrm{~F}$. heteroclitus eggs, was also successful. The eggs developed in petri dishes containing brackish water $(3.9,00)$ at $20-25^{\circ} \mathrm{C}$ and hatched in 14-20 days. The larvae were transferred to larger containers and survived for three weeks, at which time the experiment was terminated. Larvae resembled the species of the maternal parent. 


\section{Discussion}

Fundulus luciae is a hardy, euryhaline species capable of tolerating the temperature and salinity fluctuations and oxygen deficiencies associated with the high intertidal salt marsh. It was collected at Fox Creek Marsh from waters of $4-36^{\circ} \mathrm{C}$. Jorgenson (1969) collected specimens from $36.1^{\circ} \mathrm{C}$. F. Iuciae occurred in fresh water at For Creek Marsh and was taken from 0.4\% by Richards and Bailey (1967). It has been reported by Jorgenson (1969), Richards and Bailey (1967) and Griffith (1974) from salinities exceeding 27\% and de Sylva et al. (1962) collected the species from 41\%. Griffith (1974) determined F. 1uciae could tolerate salinities as high as $100 \%$ but could not endure abrupt transfer from saline to fresh water. Tolerance of fresh water was achieved by gradual acclimation, but substantial mortalities still occurred within a few months. Apparently F. 1uciae can endure impermanent fresh water conditions, as existed at the Fox Creek Marsh collection site, but not a constant fresh water environment. At Fox Creek Marsh F. luciae occurred in water containing $\langle 1.0 \mathrm{mg} / 1$ dissolved oxygen. Morphological and perhaps physiological adaptations enable F. 1uciae and other cyprinodonts to inhabit oxygen deficient waters. Srivastava and Griffith (1974) measured erythrocyte sizes of 20 Fundulus species and correlated small blood cell 
size, as possessed by $\underline{F}$ luciae, with existence in oxygen deficient habitats. Small cells may represent an adaptation to such environments because they have greater surface/ volume ratios, and thus permit more efficient gas exchange. The upturned mouths and flattened heads of cyprinodonts represent morphological adaptations which permit utilization of the oxygen rich layer of water at the air-water incerface during conditions of oxygen deficiency (Lewis 1970).

F. Iuciae has erroneously been considered rare, because its high marsh habitat has been overlooked. Collection records usually reported the species was infrequently captured during an ichthyofaunal survey of a large area. Such surveys commonly employ seine nets to collect shallow water fishes and stations are established only where use of the nets is feasible. The densely vegetated, soft-bottomed marsh pools and ditches where F. 1uciae was found in abundance would naturally be excluded.

Although not rare, the spotfin killifish was found to be only locally abundant. The environmental stress which this species is capable of enduring suggests it should be more widespread and numerous than is actually the case. Three factors may contribute to its restricted, sporadic distribution: short life span, small size and low fecundity.

Distinct annuli were not observed on scales of $F$. luciae, but a life span of only about one year is implied by the small maximum size attained by the species. F. heteroclitus and F. diaphanus possess virtually the same 


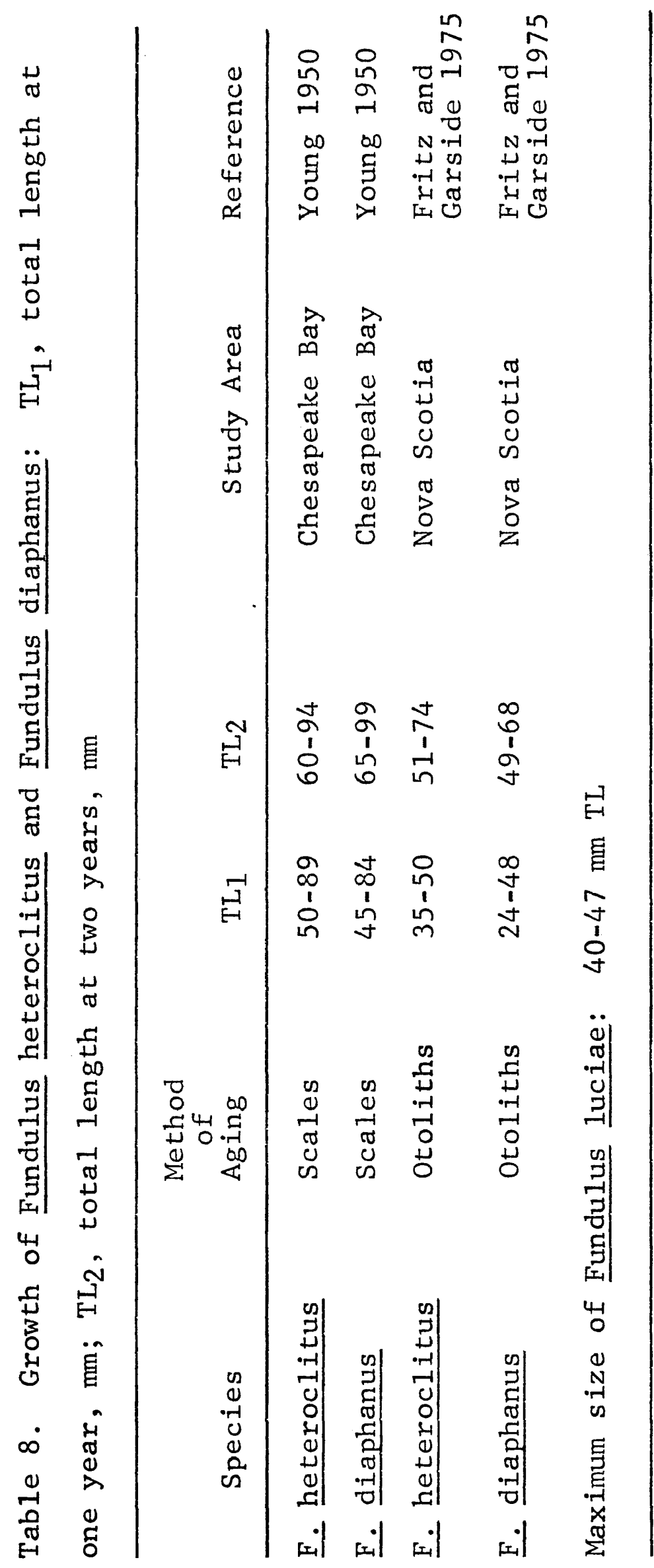


size eggs and lengths at hatching as F. 1uciae. After one year of growth their size approximates the maximum size attained by the spotfin killifish (Table 8). If the growth rate of $\mathrm{F}$. 1uciae is similar to the growth rates of these two species, then most spotfin killifish do not survive much longer than one year. Reproduction would be limited to one season and populations would consist of only two year classes.

The small size attained by $\underline{F}$. Iuciae may prevent its colonization of adjacent tidal creeks and low marsh areas. These environments would expose the species to strong daily tidal currents, which it may not be able to withstand, and predators, such as large fish and crabs. The high intertidal marsh provides a refuge from these elements.

Small size certainly limits fecundity. Mature $\underline{F}$. Iuciae ova are about $2 \mathrm{~mm}$ in diameter and the ovary of an average size female cannot contain many. The greatest number found within one female was 16 . Ovarian size restrictions may be somewhat compensated if several individual spawnings occur during a breeding season. The spawning season would necessarily be protracted, which is the case. Females containing mature ova were collected at Fox Creek Marsh from mid-April to mid-August and Hildebrand and Schroeder (1928) reported F. 1uciae spawned from April to October at Beaufort, N. C. This compensatory reproductive strategy is further supported by the continuous gradation in egg size exhibited by females during the 
breeding season. Hildebrand (1917) found several sizes of eggs simultaneously present in ovaries of Cyprinodon $\underline{\text { variegatus }}$ and demonstrated that a single female was capable of spawning numerous times during the reproductive season. Boyd and Simmonds (1974) induced F. heteroclitus to spawn throughout the year by maintaining a brood stock in a special aquarium system. The release of eggs over an extended period obviously permits greater fecundity than single spawning. Foster (1967) believes this reproductive strategy is characteristic of cyprinodonts in general.

Foster (1967) has stated that many species of killifish appear to spawn almost daily in captivity for periods of two months or longer. Such continuity was not displayed by Fundulus luciae in the natural environment. The mean number of mature ova per female seemed dependent on collection date (Table 2) and exhibited a bimodal distribution of either $\leq 1.0$ or $\geq 6.0$ eggs per fish. Such dependence and bimodality would not be expected if individual females were spawning daily. Schmelz (1964) found spawning activity of $\mathrm{F}$. heteroclitus increased around new and full moons. Spawning of F. luciae appeared to be synchronous, but was correlated with neither lunar nor tidal cycles.

Foster (1967) described sexual behavior of male cyprinodonts which included looping, circling, headflicking, headbobbing and other activities. The behavior exhibited by F. luciae males seems conservative and simple by comparison. Some behavior may have been overlooked, however, because of insufficient observation. 
Cyprinodont contact organs are restricted to males, but occur on many species and are present on those parts of the body and fins which consistently come into contact with the female during courtship and spawning (Foster 1967). The contact organs of $\mathrm{F}$. luciae males conform to this distribution. The sides of the head and body contact the female during side by side swimming, as do the distal portions of the medial fins when they are bent toward and around the female. The report by Fowler (1916) that contact organs do not occur on F. 1uciae is incorrect.

Fundulus luciae spawning sites were not detected in the natural environment, but the deposition of eggs in spawning mops in aquaria suggests a fibrous substrate may be utilized. The adhesive filaments possessed by the eggs probably serve to anchor them to the substrate and, by the attachment of particulate detritus, camouflage them from potential predators.

The spawning, embryonic development and hatching of eggs in $0.1,3.9$ and $16.9 \%$ attests to the euryhalinity of the spacies. The ability of adult F. luciae to spawn and produce viable larvae in fresh water contrasts with the inability of adults to tolerate fresh water conditions for a prolonged period, but long-term development of larvae in fresh water was not monitored. The delayed hatching exhibited by eggs in 16.9\% warrants further investigation. Delayed hatching has been reported for other cyprinodonts. Milkman (1954) was able to delay hatching of $F$. heteroclitus eggs by placing 
recently fertilized ova in a flask, bubbling in oxygen and then sealing the flask. He demonstrated that although extra oxygen had an inhibitory effect on hatching, it alone was not responsible for the inhibition observed. Harrington (1959) observed delayed hatching in F. confluentes eggs exposed to desiccating conditions. One egg produced a viable larva after 95 days. Ishida (1944a, 1944b) examined the effects of tonicity and electrolytes on hatching in Oryzia latipes. He found hatching was accelerated by hypotonic solutions of $\mathrm{KCl}$ and $\mathrm{NaCl}$ and hypertonic solutions of $\mathrm{NaCl}$, but was inhibited by hypertonic solutions of KCI and $\mathrm{CaCl}_{2}$. Hatching of $\mathrm{F}$. luciae eggs seems inhibited by salinity, but other factors may be responsible and cannot be discounted.

The life cycle of the spotfin killifish is apparently completed within one locality and does not involve migrations. At Fox Creek Marsh larvae and juveniles were captured in the same location as adults, where the spacies was present throughout the year. Recent offspring feed and grow throughout the summer, fall and winter, which is usually mild in Virginia, and are ready to spawn in April. Gamete maturation is probably induced by increasing temperature and day length. Foster (1967) observed that the postreproductive life of females of several cyprinodont species was short. Male and female F. luciae probably do not survive to spawn a second year. 
The variety of items found within the digestive tract of $\underline{F}$. luciae indicates the species is non-specific in its food habits. It is probably opportunistic as we11, feeding on those items most often encountered. The seasonal abundance of Homoptera in the diet of F. luciae probably reflects their seasonal abundance in nature and is an example of opportunistic feeding. Hildebrand and Schroeder (1928) reported crustaceans, mollusks and annelid worms in the stomachs of nine F. Iuciae. Mollusks and annelids were rare in specimens examined during the present study. Differences in the fauna available for consumption may account for this discrepancy.

The feeding behavior displayed by $\underline{F}$. luciae was similar to that described for other funduline killifishes by Foster (1967). The ability of F. Iuciae to jump and successfully capture organisms above the surface of the water demonstrates the keen vision it possesses. Jumping has also been reported in $\mathrm{F}$. heteroclitus (Chidester 1916).

Dillon (1966) has listed parasites reported from Fundulus species. All of the groups and most of the genera observed on F. luciae are included in the 1ist, though none are reported from F. 1uciae. The only parasite previously reported from the spotfin killifish is oodinium cyprinodontum, a dinoflagellate found on the gills (Lawler 1968).

Many of the organisms parasitizing F. luciae were immature, indicating the species may be an important 
intermediate host. Except for the Monogenea, the incidence of parasites was not particularly high. Their presence is probably detrimental, especially when larger species such as Eustrongyloides occur. Sufficient numbers of parasites may great1y contribute to or cause mortality.

Hybridization between cyprinodont species has been found to occur both in nature (Hubbs, Walker and Johnson 1943) and in the laboratory (Hubbs and Drewry 1959, 1962). Ability to hybridize presumably reflects genetic compatibility and indicates a close relationship between the parental species. The successful reciprocal crosses of $\underline{F}$. Iuciae and $F$. heteroclitus in the laboratory therefore implies a close relationship between them. Karyological confirmation was not obtained, however, so parthenogenetic development cannot be discounted. The successful crossing of these sympatric species indicates hybridization in nature may occur and suggests the importance of reproductive behavior in its prevention. 


\section{LITERATURE CITED}

Baird, S. F. 1855. Report to the secretary of the Smithsonian Institution on the fishes of the New Jersey coast as observed in the summer of 1854 . Ninth Annu. Rep. Smithsonian Inst. Pages 317-337.

Boyd, J. F. and R. C. Simmonds. 1974. Continuous laboratory production of fertile Fundulus heteroclitus (Walbaum) eggs lacking chorionic fibrils. J. Fish Biol. 6: 389-394.

Brown, J. L. 1954. A review of the cyprinodont genus Fundulus of the eastern United States. M.S. Thesis. Cornell University.

Butner, A. and B. H. Brattstrom. 1960. Local movement in Menidia and Fundulus. Copeia 1960(2): 139-141.

Chen, T. R. 1971. A comparative chromosome study of twenty killifish species of the genus Fundulus (Teleostei: Cyprinodontidae). Chromosoma 32(4): 436-453.

Chidester, F. E. 1916. A biological study of the more important of the fish enemies of the salt marsh mosquitoes. Bull. 300 N. J. Agr. Exp. Sta. Pages 1-16.

Crawford, D. R. 1920. Notes on Fundulus 1uciae. Aquatic Life 5: 75-76.

Cressey, R. F. 1972. The genus Argulus (Crustacea: Branchiura) of the United States. U. S. Environ. Protect. Agency Water Pollut. Cont. Res. Ser. 18050 ELD02/72. U. S. Government Printing Office, Washington, D. C. 13 pp.

de Sylva, D. P., F. A. Kalber, Jr. and C. N. Shuster, Jr. 1962. Fishes and ecological conditions in the shore zone of the Delaware River estuary, with notes on other species collected in deeper water. Univ. Del. Mar. Lab. Inform. Ser. Publication 5. 164 pp.

Dillon, W. A. 1966. Provisional list of parasites occurring on Fundulus spp. Va. J. Sci. 17 (1): 21-31. 
Fernando, C. H., J. I. Furtado, A. V. Gussev, G. Hanek and S. A. Kakonge. 1972. Methods for the study of freshwater fish parasites. University of Waterloo. Biol. Ser. No. 12. 76 pp.

Foster, N. R. 1967. Comparative studies on the biology of killifishes (Pisces: Cyprinodontidae). Ph.D. Thesis. Corne11 University. 369 pp.

Fowler, H. W. 1912. Records of fishes for the middle Atlantic States and Virginia. Proc. Acad. Natur. Sci. Phila. 64: 34-59.

Fowler, H. W. 1914. Notes on the fishes at Ocean City, Maryland. Copeia 1914(2): 2-3.

Fowler, H. W. 1916. Some features of ornamentation in the killifishes or toothed minnows. Amer. Natur. 50(600): 743-750.

Fowler, H. W. 1927. Notes on fishes in Delaware, 1925-26. Copeia 1927(165): 90-91.

Fritz, E. S. and E. T. Garside. 1975. Comparison of age composition, growth, and fecundity between two populations each of Fundulus heteroclitus and F. diaphanus (Pisces: Cyprinodontidae). Can. J. Zoo1. 53(4): 361-369.

Griffith, R. W. 1974. Environment and salinity tolerance in the genus Fundulus. Copeia 1974(2): 319-331.

Harrington, R. W., Jr. 1959. Delayed hatching in stranded eggs of marsh killifish, Fundulus confluentes.

Ecol. 40(3): 430-437.

Hildebrand, S. F. 1917. Notes on the life history of the minnows Gambusia affinis and Cyprinodon variegatus. Rep. U. S. Comm. Fish. 1917: 1-15.

Hildebrand, S. F. 1941. An annotated list of salt and brackish water fishes, with a new name for menhaden, found in North Carolina since the publication of "The fishes of North Carolina" by Hugh M. Smith in 1907. Copeia 1941(4): 220-232.

Hildebrand, S. F. and W. C. Schroeder. 1928. Fishes of Chesapeake Bay. Bull. U. S. Bur. Fish. 43 (1): $1-388$.

Hoffman, G. L. 1967. Parasites of North American freshwater fishes. University of California Press, Berkeley. 486 pp. 
Hubbs, Car1 L., B. W. Walker and R. E. Johnson. 1943. Hybridization in nature between species of American cyprinodont fishes. Contrib. Lab. Vertebrate Biol. Univ. Mich. 23: 1-21.

Hubbs, Clark and G. E. Drewry. 1959. Survival of F1 hybrids between cyprinodont fishes, with a discussion of the correlation between hybridization and phylogenetic relationship. Publications Inst. Mar. Sci. Univ. Tex. 6: $81-91$.

Hubbs, Clark and G. E. Drewry. 1962. Artificial hybridization of Crenichthys baileyi with related cyprinodont fishes. Tex. J. Sci. 14(1): 107-110.

Humason, G. L. 1972. Animal tissue techniques. W. H. Freeman and Co., San Francisco. 641 pp.

Ishida, J. 1944a. Hatching enzyme in the fresh-water fish, Oryzias latipes. Annot. Zoo1. Jap. 22: 137-154.

Ishida, J. 1944b. Further studies of the hatching enzyme of the fresh-water fish, Oryzias latipes. Annot. Zool. Jap. 22: 155-164.

Jorgenson, S. C. 1969. A Georgia record for the cyprinodontid fish, Fundulus luciae. Chesapeake Sci. 10(1): 65 .

Lawler, A. R. 1968. New host record for the parasitic dinoflagellate Oodinium cyprinodontum Lawler, 1967. Chesapeake Sci. 9(4): 263.

Lewis, W. M., Jr. 1970. Morphological adaptations of cyprinodontoids for inhabiting oxygen deficient waters. Copeia 1970(2): 319-326.

Meehean, O. L. 1940. A review of the parasitic Crustacea of the genus Argulus in the collections of the United States National Museum. Proc. U. S. Nat. Mus. 88(3087): 459-522.

Milkman, R. 1954. Controlled observation of hatching in Fundulus heteroclitus. Biol. Bull. 107(2): 300 . (Abstr.)

Miller, G. L. and S. C. Jorgenson. 1973. Meristic characters of some marine fishes of the western Atlantic Ocean. Fish. Bu11. 71(1): 301-312.

Nichols, J. T. and C. M. Breder, Jr. 1927. The marine fishes of New York and southern New England. Zool. $9(1): 1-192$. 
Richards, C. E. and R. L. Bailey. 1967. Occurrence of Fundulus luciae, spotfin killifish, on the seaside of Virginia's Eastern Shore. Chesapeake Sci. $8(3)$ : 204-205.

Richards, C. E. and M. Castagna. 1970. Marine fishes of Virginia's Eastern Shore (inlet, marsh and seaside waters). Chesapeake Sci. 11: 235-248.

Roberts, L. S. 1970. Ergasilus (Copepoda: Cyclopoida): revision and key to species in North America. Trans. Amer. Microscop. Soc. 89(1): 134-161.

Rosen, D. E. 1973. Suborder Cyprinodontoidei. Pages 229-262 in D. M. Cohen, ed. Fishes of the western North Atlantic, Part 6. Sears Found. Mar. Res., Yale University.

Schmelz, G. W. 1964. A natural history study of the mummichog, Fundulus heteroclitus, in Canary Creek Marsh. M.S. Thesis. University of Delaware.

Smith, H. M. 1892. Notes on a collection of fishes from the lower Potomac River, Maryland. Bull. U. S. Fish. Comm. 10: 63-72.

Srivastava, A. K. and R. W. Griffith. 1974. Erythrocyte morphology and the ecology of species of Fundulus. Copeia 1974(1): 136-141.

Strickland, J. D. H. and T. R. Parsons. 1968. A practical handbook of seawater analysis. Fish. Res. Board Can. Bull. 167. 311 pp.

Wiley, M. L. and B. B. Collette. 1970. Breeding tubercles and contact organs in fishes: their occurrence, structure, and signifigance. Bull. Amer. Mus. Natur. Hist. 143(3): 143-216.

Yamaguti, S. 1961. Systema Helminthum. Vol. III, 2 parts. The nematodes of vertebrates. Interscience Publishers, New York. 1,261 pp.

Yamaguti, S. 1963a. Systema Helminthum. Vo1. IV. Monogenea and Aspidocotylea. Interscience Publishers, New York. 699 pp.

Yamaguti, S. 1963b. Systema Helminthum. Vo1. V. Acanthocephala. Interscience Publishers, New York. $423 \mathrm{pp}$.

Yorke, W. and P. A. Maplestone. 1962. The nematode parasites of vertebrates. Hafner Publishing Co., New York. 536 pp. 
Young, K. M. 1950. Observations on the distribution and growth of the genus Fundulus in the upper Chesapeake Bay. M.S. Thesis. University of Maryland. 49 pp. 
VITA

\section{Dona1d Michae1 Byrne}

Born in Teaneck, New Jersey, October 26, 1949. Graduated from New Milford High School in New Milford, New Jersey, June 1967, B.A., University of Virginia, 1971. Employed by Virginia Institute of Marine Science as 1aboratory technician, Department of Physical Oceanography, September 1971 - February 1972, and laboratory specialist, Department of Microbiology-Pathology, March 1972 February 1974 .

In September 1972, the author entered the College of William and Mary, Department of Marine Science and in May 1974, became a graduate assistant in the Department of Ichthyology. 